\title{
Between activism and science: grassroots concepts for sustainability coined by Environmental Justice Organizations
}

\author{
Joan Martinez-Alier ${ }^{\text {a } 1}$ \\ Isabelle Anguelovski ${ }^{\text {a }}$ \\ Patrick Bond ${ }^{\mathrm{b}}$ \\ Daniela Del Bene ${ }^{\mathrm{a}}$ \\ Federico Demaria ${ }^{a}$ \\ Julien-Francois Gerber ${ }^{c}$ \\ Lucie Greyl $^{\mathrm{d}}$ \\ Willi Haas ${ }^{e}$ \\ Hali Healy ${ }^{a}$ \\ Victoria Marín-Burgos ${ }^{\mathrm{f}}$ \\ Godwin Ojo ${ }^{g}$ \\ Marcelo Porto ${ }^{\mathrm{h}}$ \\ Leida Rijnhout ${ }^{\mathrm{i}}$ \\ Beatriz Rodríguez-Labajos ${ }^{\text {a }}$ \\ Joachim Spangenberg $^{\mathrm{j}}$ \\ Leah Temper ${ }^{a}$ \\ Rikard Warlenius ${ }^{\mathrm{k}}$ \\ Ivonne Yánez ${ }^{1}$ \\ ${ }^{a}$ Autonomous University of Barcelona, Spain \\ ${ }^{\mathrm{b}}$ University of KwaZulu-Natal, South Africa \\ ${ }^{\mathrm{c}}$ Teri University, India \\ ${ }^{d}$ Centro di Documentazione sui Conflitti Ambientali, Italy \\ ${ }^{\mathrm{e}}$ University of Klagenfurt, Austria \\ ${ }^{\mathrm{f}}$ University of Twente, the Netherlands \\ ${ }^{g}$ Environmental Rights Action, Nigeria \\ ${ }^{\text {h }}$ Fundaçao Olwaldo Cruz, Brazil \\ ${ }^{\mathrm{i}}$ European Environmental Bureau, Belgium \\ ${ }^{j}$ Sustainable Environment Research Institute, Germany \\ ${ }^{\mathrm{k}}$ Lund University, Sweden \\ ${ }^{1}$ Acción Ecológica, Ecuador
}

\footnotetext{
1 Prof. Joan Martinez-Alier, Emeritus Professor, ICTA, Universitat Autonoma de Barcelona, Spain. Email: joan.martinez.alier "at" uab.cat. This article draws on reports, books and meetings from two "Science-in-Society" collaborative research projects funded by FP7 programs of the European Commission, coordinated by the ICTA, Universitat Autonoma de Barcelona: CEECEC (Civil Society Engagement with Ecological Economics 2008-2010), (Healy et al., 2012) and EJOLT (Environmental Justice Organizations, Liabilities and Trade, 2011-2015), (www.ejolt.org). We are also grateful to project CSO2010-21979 on Social Metabolism and Environmental Conflicts, and the reviewers and editors, particularly Simon Batterbury.

Citation: Martinez-Alier J., Anguelovski I., Bond P., Del Bene D., Demaria F., Gerber J.-F., Greyl L., Haas W., Healy H., Marín-Burgos V., Ojo G., Porto M., Rijnhout L., Rodríguez-Labajos B., Spangenberg J., Temper L., Warlenius R.. and I.Yánez. 2014. Between activism and science: grassroots concepts for sustainability coined by Environmental Justice Organizations. Journal of Political Ecology 21: 19-60.
} 


\begin{abstract}
In their own battles and strategy meetings since the early 1980s, EJOs (environmental justice organizations) and their networks have introduced several concepts to political ecology that have also been taken up by academics and policy makers. In this paper, we explain the contexts in which such notions have arisen, providing definitions of a wide array of concepts and slogans related to environmental inequities and sustainability, and explore the connections and relations between them. These concepts include: environmental justice, ecological debt, popular epidemiology, environmental racism, climate justice, environmentalism of the poor, water justice, biopiracy, food sovereignty, "green deserts", "peasant agriculture cools downs the Earth", land grabbing, Ogonization and Yasunization, resource caps, corporate accountability, ecocide, and indigenous territorial rights, among others. We examine how activists have coined these notions and built demands around them, and how academic research has in turn further applied them and supplied other related concepts, working in a mutually reinforcing way with EJOs. We argue that these processes and dynamics build an activist-led and co-produced social sustainability science, furthering both academic scholarship and activism on environmental justice.
\end{abstract}

Keywords: Political ecology, environmental justice organizations, environmentalism of the poor, ecological debt, activist knowledge

\title{
Résumé
}

Depuis le début des années 80, à travers leurs propres luttes et réunions stratégiques, les EJOS (Organisations de Justice Environnementale) et leurs réseaux ont introduit quelques concepts différents d'écologie politique qui ont été repris par le monde académique et par les décideurs politiques. Dans cet article, nous expliquons les contextes qui ont promu l'émergence de ces concepts, et offrons des définitions pour un large ensemble de concepts et de slogans lies aux inégalités environnementales et à la protection durable de l'environnement, et nous explorons les connections entre eux. Ces concepts incluent: La justice environnementale, la dette écologique, l'épidémiologie populaire, le racisme environnemental, la justice climatique, l'environnementalisme des pauvres, la justice hydrique, la bio-piraterie, la souveraineté alimentaire, «les déserts verts», «l'agriculture paysanne rafraichit la terre», la prise des terres (land grabbing), l'Ogonisation et la Yasunisation, les plafonds de ressources, la responsabilité des entreprises, l'écocide, les droits indigènes territoriaux, et quelques autres. Nous examinons comment les activistes ont inventé ces termes, construit des demandes autour d'eux, et comment la recherche académique les a appliqués, et ensuite comment elle a offert de nouveaux concepts, travaillant de manière symbiotique avec les EJOS. Nous argumentons que ces processus et dynamiques construisent une science du développement durable conduite et co-produite par les activistes, ce qui renforce ainsi la littérature académique et l'activisme sur la justice environnementale.

Mots-clés: Ecologie politique, organisations de justice environnementale, environnementalisme des pauvres, dette écologique, connaissance activiste

\section{Resumen}

Desde el inicio de la década de 1980, las OJAs (organizaciones de justicia ambiental) y las redes que ellas forman introdujeron diversos conceptos de ecología política en sus campañas y en sus reuniones para determinar estrategias, que han sido adoptados también por académicos y por tomadores de decisiones. En este artículo explicamos los contextos que dieron lugar a esas nociones, compilamos muchos conceptos y lemas que se refieren a inequidades ambientales y a la sustentabilidad, examinando sus interrelaciones. Dichos conceptos incluyen, entre otros, los siguientes: justicia ambiental, deuda ecológica, epidemiología ambiental, racismo ambiental, justicia climática, ecologismo de los pobres, justicia hídrica, biopiratería, soberanía alimentaria, "desiertos verdes", el lema "la agricultura campesina enfría la Tierra", acaparamiento de tierras, Ogonización y Yasunización, topes al uso de recursos, pasivos ambientales y responsabilidad ambiental empresarial, ecocidio y derechos territoriales indígenas. Estudiamos cómo los activistas de las OJAs acuñaron tales conceptos configurando exigencias políticas a partir de ellos, y cómo los investigadores académicos también los han aplicado $\mathrm{y}$, a su vez, han aportado otros conceptos, en un proceso de fortalecimiento mutuo. Estos procesos y dinámicas dirigidos por activistas co-producen y construyen una ciencia social de la sustentabilidad, que apoya tanto el trabajo científico como el activismo, favoreciendo así nuevos logros en favor de la justicia ambiental.

Palabras clave: Ecología política, organizaciones de justicia ambiental, ecologismo de los pobres, deuda ecológica, conocimiento activista 


\section{Introduction}

We review a set of concepts of political ecology that have origins outside academia. They have been produced by civil society organizations and often by one specific form of NGO, the EJOs (environmental justice organizations) that are leading the global environmental justice movement. EJOs are organizations that constitute networks; sometimes they are formed by members of a community organized ad hoc as a platform or as a coordinating committee for a specific cause, and sometimes they are permanent groups with lives stretching over twenty or more years. On their own, or sometimes with the help of sympathetic academics, the EJOs have introduced or adopted powerful concepts and principles to analyze and to cope with environmental conflicts. They have produced a "political ecology from the bottom up". There is usually a period of five to ten years between the time when a new concept is introduced by civil society at the cutting edge of the global environmental justice movement, and the time when the same concept becomes an object of mainstream research in the academic literature dealing with social sustainability. Through a review of the definitions and the dates of origin of such concepts, we show that they are thematically connected, and applied at different geographical scales. Here, civil society organizations and academics indirectly strengthen each other's "mission" through an iterative process of examining and analyzing events, claims, strategies, and conflicts.

\section{Environmental justice}

The first concept in our list of activist contributions to the social sustainability sciences is Environmental Justice (EJ) born (in its sociological usage) in the United States, in struggles against waste dumping in North Carolina in 1982 (Figure 1). Activist-authors such as Robert Bullard (1990), civil rights activists with no academic affiliation, and members of Christian churches saw themselves as militants of environmental justice. By 1991, a large assembly in Washington DC proclaimed the principles of Environmental Justice. This history is well known. Since the 1980s, hundreds of reports have shown that "people of color" and low-income populations have suffered from greater environmental harm from waste sites, incinerators, refineries, transportation infrastructures than white and well-off communities (Bryant and Mohai 1992; Bullard 1990; Downey and Hawkins 2008; Lerner 2005; Mitchell and Dorling 2003; Pellow 2000; Sze 2006; Varga et al. 2002). Workers from poor and 'minority' backgrounds are more likely to be exposed to toxic pesticides and hazardous waste (Harrison 2011; Pellow 2002; Pellow and Park 2002; Smith et al. 2006). Some years ago a new term emerged from the EJ movement, that of sacrifice zones. It has been used in Latin America and no doubt it is appropriate for some regions of Africa and Asia. In the US, Samuel Lerner (2010) told the stories of twelve communities that rose up to fight industries and military bases that were causing disproportionately high levels of chemical pollution. He called these low-income neighborhoods sacrifice zones.

The fight against the disproportionate incidence of pollution in predominantly Black, Hispanic or Indigenous communities was seen by activists both as a fight for environmental justice and as a fight against environmental racism (a concept coined in 1982 by activist Rev. Benjamin Chavis, a trained chemist). ${ }^{2}$ This concept traveled well beyond the United States. In the EJOs' idiom, environmental racism means the bad treatment inflicted on people in the form of pollution or resource extraction on the grounds of membership in particular ethnic groups, social class or caste. Thus, one can say that in the Niger Delta, Nigeria, Shell and other oil companies exhibit environmental racism. They have shifted the social and environmental costs of oil extraction onto indigenous, poor local communities.

For many groups fighting environmental racism, social class comes second to issues of racial discrimination, while for other EJOs economic disadvantage is the most important criteria. In India, caste (e.g. the poor treatment of Dalits) is an important consideration, while tribal affiliation often counts in many other countries in the struggles against resource extraction (Kowasch 2012). While in the US "people of color" and poor people are "minorities", in the world at large they are a majority, and therefore this offers a great potential for a worldwide EJ movement.

\footnotetext{
${ }^{2}$ http://drbenjaminchavis.com/pages/landing/?blockID=73318 (accessed 4 Jan. 2014).
} 


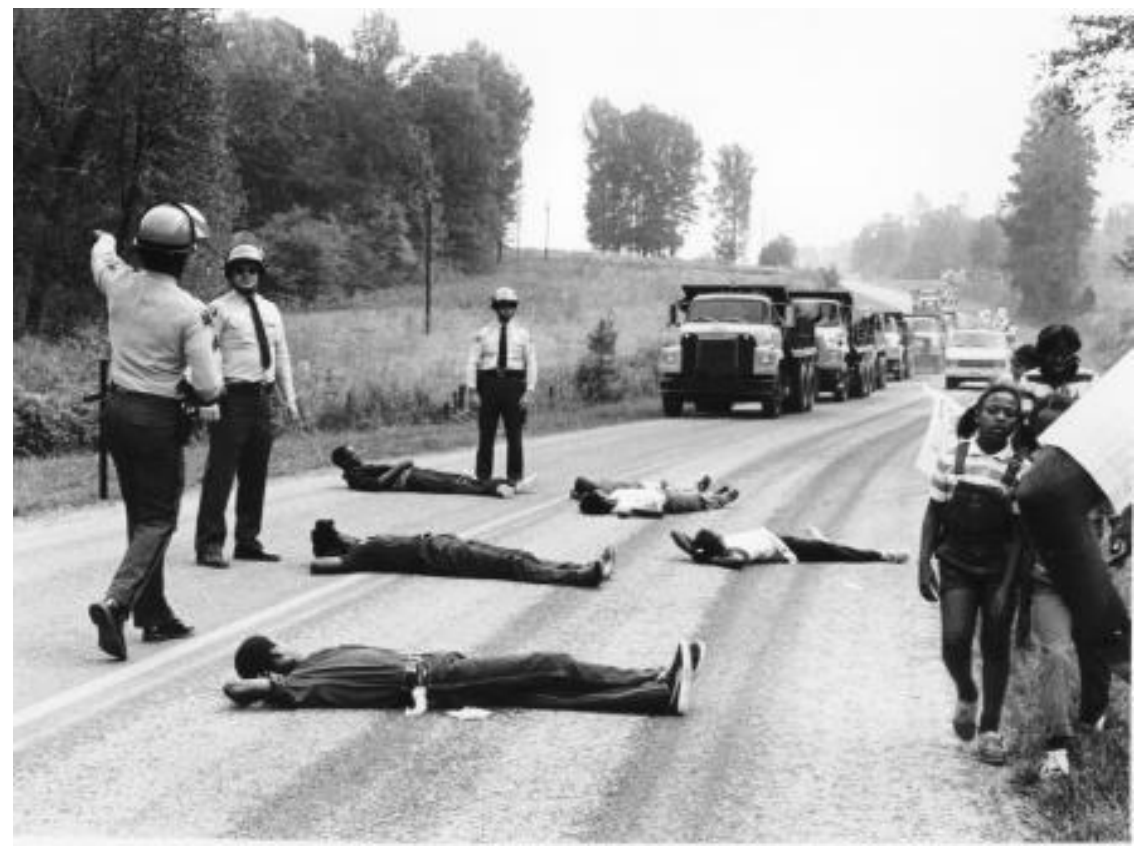

Figure 1: Environmental justice: protests against dumping PCB contaminated soil in an African-American community, Warren County, North Carolina, 1982. Source: Jenny Labalme, 1987, A road to walk - a struggle for environmental justice (with permission).

The struggles against environmental injustice are growing, and the name EJ is now used more frequently outside the USA. Thus, in Mozambique there is a very active group with the name of Justiça Ambiental (a member of Friends of the Earth International). In Brazil there has been a Network of Environmental Justice since 2001, formed by EJOs, unions, indigenous groups and university researchers. ${ }^{3}$

Over the years, the US Environmental Justice movement helped reframe traditional definitions to better fit the realities of the populations that EJOs are defending. For instance, in the 1991 First National People of Color Environmental Leadership Summit, EJ groups redefined the environment as a safe place to live, work, learn, a definition that has been used by public health and planning experts as they examine the relation between health and place, e.g. in studying the incidence of asthma (Maantay 2007). Urban ecology scholars have used this definition as they examine new forms of EJ claims in cities, such as healthy communities, or place-remaking and community reconstruction within degraded marginalized neighborhoods (Agyeman et al. 2003; Anguelovski 2014; Corburn 2009).

\section{Popular epidemiology}

Evidence of the disproportionate incidence of morbidity or mortality is not always available from official statistics because of the lack of health professionals, hospitals or reliable information systems in the areas concerned, making the problem invisible. Hence the rise of so-called popular epidemiology, a concept of relevance in many struggles inside and outside the United States (Figure 2). Think for instance of efforts by the plaintiffs in the Ecuadorian Chevron-Texaco case in the 2000s to gather information related to the incidence of cancer in the Sucumbíos region of the Amazon in the 1970s and 1980s. They resorted to the memories of the local populations, drawing on studies that proved that such memories concentrated around areas with oil wells, transfer stations, and pools for disposal of extraction water (Martin Beristain et al. 2009). Popular epidemiology (Brown 1992, 1997) implies that "lay" knowledge of illnesses from pollution is

\footnotetext{
${ }^{3}$ A map of environmental injustices in Brazil, with 400 cases, has been built by Dr Marcelo Firpo Porto of ENSP (Fiocruz) and collaborators (Porto et al., 2013): http://www.conflitoambiental.icict.fiocruz.br.
} 
more valid than (the sometimes non-existent) official knowledge. Popular epidemiology is at least an early warning system, a complement to, and partly a substitute for "normal" scientific epidemiological studies.

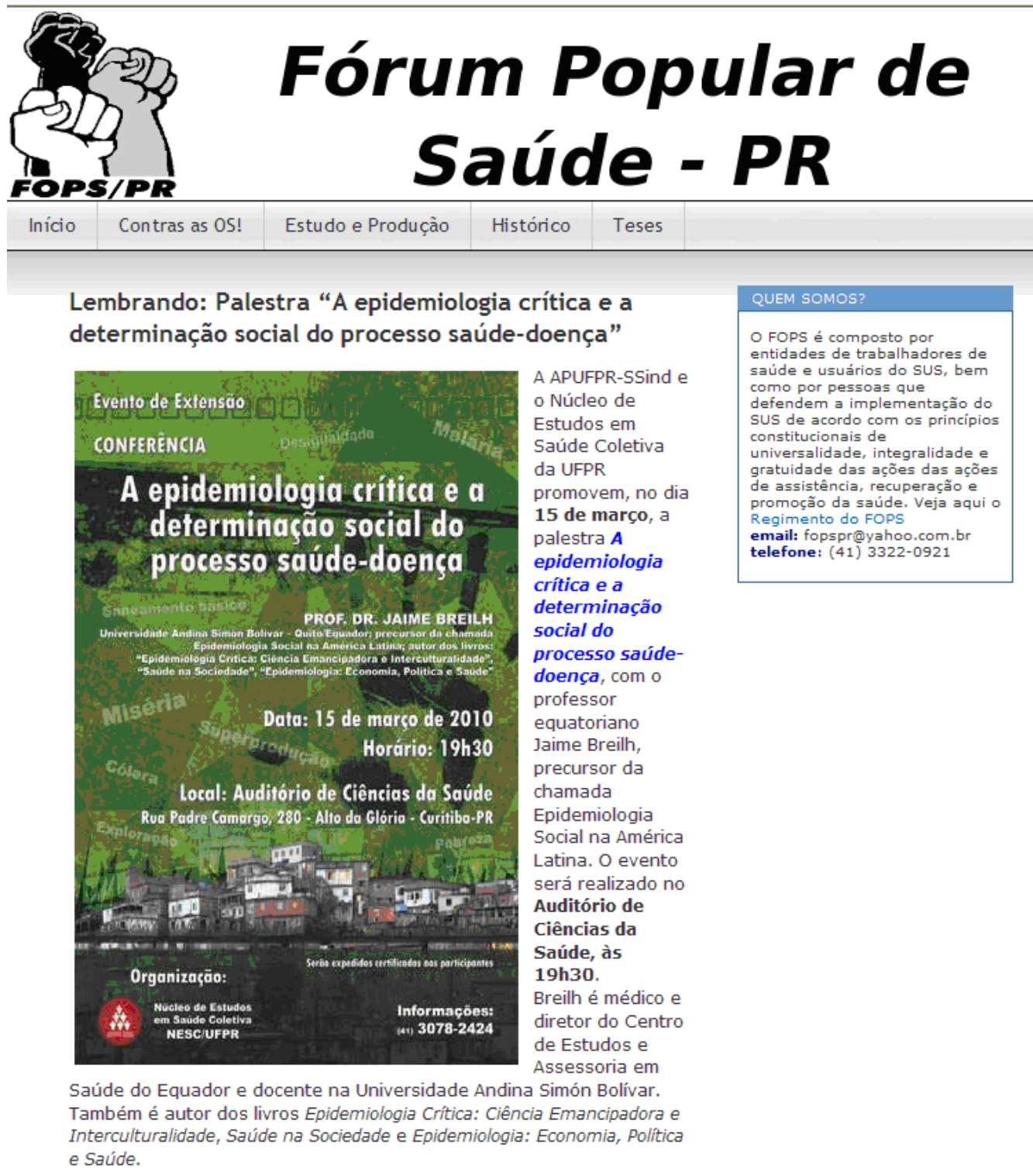

Figure 2: Popular epidemiology: Web site of the Health Popular Forum, Curitiba, Brazil, announcing a talk on critical epidemiology, March 10, 2010. Source: FOPS-Curitiba, Parana http://fopspr.wordpress.com/sobre

The concept of popular epidemiology fits with the "post-normal science" approach which has been influential in ecological economics (Funtowicz and Ravetz 1993). The apparent neutrality and objectivity of normal science is criticized because in many situations it makes hard facts explicit whilst concealing both the values and the uncertainties in question, often neglecting local-situated knowledge and hiding hegemonic interests. A similar critique is made by EJ activists, pointing out the need for integrating perspectives, values, and legitimate lay knowledge (Porto 2012a). Post-normal science appeals to, or at least accepts, an "extended peer review" in such situations, with participation of activist or other lay experts. Academics also talk about "street science" through which the daily experiences of residents with environmental contamination and 
dumping supports academic research and traditional professional research techniques, and can in turn be used to support legal claims and demands (Corburn 2005).

When detailed and autonomous scientific studies are undertaken analyzing the findings from popular epidemiology, they usually confirm them. However, such studies are often not available, or they are not supported by industries or risk-makers. Thus, popular epidemiology is not just an early warning system, or a complement to and a partial substitute for normal scientific epidemiological studies. It also helps to transform affected and vulnerable populations into protagonists, breaking the mechanisms that make their problems invisible (Porto and Finamore 2012).

\section{The environmentalism of the poor}

EJOs have used the term environmentalism of the poor since the late 1980s, in activist interventions by poor and/or indigenous peoples in many struggles to defend their livelihoods against resource extraction. The term was used in Peru by agrarian activist and then senator Hugo Blanco in 1991 in an article listing several such struggles. ${ }^{4}$ In Thailand, one main grassroots rural and environmental organization is called (in English translation) the "Assembly of the Poor". Founded in 1995, it grew out of unrest against the impact of the Pak Mun dam. This is an environmentalism that contrasts with two other types: the Conservation movement and the Eco-Efficiency (or Ecological Modernization) movement (Martinez-Alier 2002, 2014).

However, some EJOs find the word "poor" derogatory to impoverished indigenous communities that lived outside the generalized market system and become dispossessed of their means of livelihood. They prefer to speak of an environmentalism of the people, an ecologismo popular (Martinez-Alier 1992). A popular environmentalism would also fit better than environmentalism of the poor with movements in rich countries against nuclear energy (since the 1970s) and also for agroecology, permaculture and today's other localist practices of la décroissance (degrowth).

Academics started to use the term environmentalism of the poor in 1988-89 (drawing on research in India and Latin America) (Guha and Martinez-Alier 1997; Martinez-Alier 2002; Nixon 2011); it was developed in similar words by Anil Agarwal, the founder of the Centre for Science and Environment (CSE) in Delhi and editor in the mid-1980s of the first "Citizens' Report" on The State of India's Environment. ${ }^{5}$ Agarwal died in 2002 and his co-author and successor at CSE, Sunita Narain, often uses the term environmentalism of the poor to refer to the many struggles in India against dams, mining projects, nuclear power stations, and also to refer to proactive collective projects for water harvesting and forest conservation. ${ }^{6}$ Poor people fight against what the Marxist geographer David Harvey calls accumulation by dispossession, a concept that more and more activists employ but which was not born in an EJO strategy meeting but in a university seminar. Thus, Sunita Narain insists that:

...virtually all infrastructure and industrial projects — from mining to thermal and hydel and nuclear power to cement or steel - are under attack today from local communities who fear loss of livelihoods. These communities today are at the forefront of India's environmental movement. They are its warriors. But for them environment is not a matter of luxury - fixing the problems of growth, but of survival - fixing growth itself. They know that when the land is mined and trees are cut, their water source dries up or they lose grazing and agricultural fields. They know they are poor. But they are saying, loudly and as clearly as they can, what we call development will only make them poorer. This is what I have called the environmentalism of the poor...The question is where do we go from here? I would argue, we need to keep listening to these voices, not dismiss or stifle them in the name of anti-growth dissent or even Naxalism ... In most cases you will find the concern raised by people is pushed

\footnotetext{
${ }^{4}$ http://hugoblancogaldos.blogspot.com.es/2008/12/el-ecologismo-de-los-pobres.html

5 The Environmentalism of the Poor, an obituary for Anil Agarwal, by Ramachandra Guha, 2002 http://cseindia.org/userfiles/Anil Agarwal EPW obit.pdf

${ }^{6}$ http://blogs.unimelb.edu.au/environment/2008/09/05/learning-from-the-environmentalism-of-the-poor-to-build-ourcommon-future/ and http://archive.truthout.org/environmentalism-poor-what-democracy-teaching-us67535 https://asunews.asu.edu/20130319_environmentalist_narain
} 
aside as projects are rammed through in the name of industrial development. This must stop.... We must understand that our future lies in being part of the environmentalism of the poor, as this movement will force us all to seek new answers to old problems. ${ }^{7}$

Sunita Narain's mention of Naxalism in some regions of India raises the question of whether environmental justice struggles and the environmentalism of the poor are essentially non-violent movements in their methods of resistance against the violence exercised against them. Non-violence was indeed the origin of the EJ movement in the USA (building on Civil Rights struggles), and it also characterized Chico Mendes' tactics of empate in Acre, Brazil. Movements in rural India are very much influenced by Gandhians. We wish this could always be the case. Nevertheless, as Godwin Ojo (2013) writes on the Niger Delta:

...for analytical brevity, environmentalism in Nigeria can be categorised under two broad headings, namely non-violent and violent environmental justice struggles. Non-violent refers to the period from the 1970s when environmental issues were becoming visible to 1999 when responses by the fledging social movements were beginning to be noticed. The violent era refers to the period of armed resistance (mainly by MEND), which started in 1999 to 2009. Suffice to say from the outset that both strategies though distinct, may have actually influenced the "leave oil in the soil" campaign.

In the Niger Delta there has been brutal violence from the state and the oil companies. In many other countries (Mexico, Brazil, Colombia, Philippines, Peru, Indonesia) the loss of human life becomes routine in ecological distribution conflicts. Company security guards, paramilitary groups, the State police and army kill or terrify protesters. One cannot be surprised that some actors resort to violent repertoires of protest. This is the exception rather than the rule, however. Moreover, it is often counterproductive.

One additional point needs to be made. First, environmental justice in the sense used here is mainly about intragenerational distribution, without forgetting intergenerational distribution, and including nondistributional dimensions of justice such as recognition and also prevention of participatory exclusions (Schlosberg 1999, 2007).

\section{Materialist ecofeminism}

Despite the social difficulties in making themselves heard, women are often in the lead in the environmentalism of the poor. Nevertheless, the EJ movements are still trying to come to terms with Feminism, which is an older and increasingly successful movement. There are nevertheless obvious links, summarized for instance by Sandra Veuthey. ${ }^{8}$ As she writes, women do not hesitate to challenge political power, local tyrants and armed violence for protecting the natural resources they and their family depend on. Therefore they protect their culture, way of life, sacred places, and livelihood means. There are two ways of interpreting such crucial role in conflicts over oil extraction, mining and logging activities, shrimp farming and plantations, and also in urban EJ struggles.

There is a current of "essentialist" ecofeminism where women and men are regarded as distinct as a result of their biological natures. Women are deemed to be biologically closer to nature than men. This has been challenged by activists and scholars arguing for a materialist ecofeminism. This materialist current is studied by feminist environmentalism (Agarwal 1992), feminist political ecology (Rocheleau et al. 1996), socialist or materialist ecofeminism (Mellor 1997; Merchant 1992), ecofeminist political economy (Mellor 2006) and feminist ecological economics (O'Hara 2009; Perkins 2007; Perkins and Kuiper 2005; Waring 1988).

Despite "participatory exclusions" (Agarwal 2001), women instigate environmental struggles, sometimes they lead and organize them, sometimes they interact with men in the conflicts, sometimes they confront men through these conflicts, and sometimes men have leading roles in struggles while women

\footnotetext{
7 Sunita Narain, in Business Standard, 10 Jan. 2011. "Hydel" means hydroelectric in India.

${ }^{8}$ http://www.wrm.org.uy/bulletinfr/152/vue.html
} 
constitute the backbone of the movement. Women's role in environmental conflicts has the potential to help achieve environmental justice as well as to simultaneously challenge local masculine domination. When women take active part in EJ struggles they often redefine their social position within their own culture, while at the same time challenging the global economy (Veuthey and Gerber 2010, 2012).

Within Feminism, one could do an analysis of the origin of concepts between activism and the academy similar to that in the present article for political ecology and environmental justice. Concepts such as the double standard of sexual behavior, the double burden of work, gender as a social construction, patriarchy, reproductive rights, the importance of caring work and of social reproduction (compared to market production), and indeed the word 'eco-feminism' itself can be traced sometimes to iconic writings most often produced outside universities (D'Eaubonne 1974). Some were probably born in the streets. For instance, D'Eaubonne's link between lack of women's freedom to exercise reproductive rights and overpopulation, drew on the social movement of radical, feminist Neo-Malthusianism of 1900 that had developed its own non-academic keywords, like la grève des ventres. ${ }^{9}$

\section{Working-class environmentalism?}

A common view is that workers are ready to sacrifice the environment and even their own health for secure jobs and higher wages. Therefore, much social distance would be expected between working class and EJ movements. There have been regularly complaints, however, by workers and their unions against bad environmental conditions in factories, mines and plantations causing ill health since the early stages of industrialization. Although waged workers might lack the emotional attachment to workplaces that indigenous peoples have to their territories or urban dwellers might have to their barrios, they are also concerned about their immediate environment, if nothing else as members of households. Compared to tribal and peasant populations, workers get money, and not livelihoods-in-kind, from their workplaces. Labor unions, however, do not just ask for wage increases and reductions of working time, but they aid improvements in working conditions. This also applies to workers in the service sector, and including domestic work.

Recently high profile court cases in the news have been over asbestos-related illness (both in factories and neighborhoods), uranium mining, and from the nematicide DBCP in banana plantations. ${ }^{10}$ Are there possibilities for alliances between EJ movements and working class movements? Environmental historian Stefania Barca (2012) asks this. She explains that workers often labor in hazardous environments, live in the most polluted neighborhoods, and have few possibilities to move to a green uncontaminated area or to buy or grow healthy food. Environmental policies should achieve sustainability from work and around it: this means reorganizing production on the basis of meaningful work, and not simply introducing technical solutions such as incineration of waste or nuclear energy which only allow the continuation of accumulation of profits while introducing new threats to workers and their communities and poor people around the world.

Barca explicitly frames working-class environmentalism as a category within the environmentalism of the poor, comparing struggles in several countries in which labor unions fought for a better environment. Much could also be learnt from contemporary working class struggles in India, China, Bangladesh and many other industrializing countries. Barca connects the health and safety grievances from unions in their workplaces to similar grievances aired at a society-wide level. She argues that the EJ movement has focused too much on the urban and rural poor and unprivileged ethnic communities, wrongly excluding working class protagonists. From an environmentalist point of view, André Gorz was mistaken in 1980 when he bade adieux au proletariat (Gorz 1982). But possible alliances between working class and environmental movements depend on common strategies about the economic-ecological transition, including issues of employment and social security.

\footnotetext{
${ }^{9}$ http://isecoeco.org/pdf/Neo-malthusianism.pdf

${ }^{10}$ On the DBCP case, Swedish director Fredick Gertten made one film, Bananas! On trial for malice (2009). He was brought to court by the Dole Food Company. He replied with another film, Big Boys gone Bananas! (2011). There is a good book on the DBCP case by Vicent Boix, El parque de las hamacas, Barcelona: Icaria, 2007.
} 


\section{The ecological debt and climate justice}

The social metabolism, i.e. the flows of energy and materials entering the economy, continues to grow. There has been no dematerialization of the world economy. Contrary to what Chinese bureaucrats, European Commissioners and opportunists of various types assert, the industrial economy based on fossil fuels cannot be a "circular" economy. It is an entropic economy that shifts costs to poor people, to future generations and onto other species. EJOs understand and take part in debates over social metabolism and the energy and material intensities of the economy, but such concepts have not been invented by them. However, they popularize them, using them for lobbying and campaigning, while adapting them (partly in collaboration with "green" research institutions) to their needs. Some academics turn into intellectual activists themselves, as Mathis Wackernagel has done by spreading and refining the ecological footprint concept initially introduced by Vancouver urban ecology professor Bill Rees in 1992.

EJOs complain about fossil fuel extraction and mining of metals, and also against the extraction of building materials or "aggregates", introducing derogatory terms (like sand mafias in India for the groups that extract sand and gravel from riverbeds and beaches). EJOs understand that even a no-growth economy, if still based on the fossil fuels, would need daily access to the new commodity frontiers to extract new supplies because energy is not recycled. Jason Moore (2000) introduced and defined the notion of commodity frontiers. He derived the term from the concept of the commodity chain, and applied it initially to sugar cane production and precious metals in colonial America in a world systems context derived from the work of Immanuel Wallerstein and André Gunder Frank. There are many recent examples of resource extraction at new commodity frontiers, and not only in the South. For instance, attempts at fracking of natural gas in France, Bulgaria, Romania and Poland have been resisted by local populations. ${ }^{11}$

While energy cannot be recycled at all, materials can be recycled to some extent. In the last decade global material flows grew by 3.5\% per year and only 6 to $9 \%$ of extracted materials were recycled (Haas et al. forthcoming). One reason for the low recycling ratio is that a great quantity of materials is used for energy production. Waste from biomass fed to humans or animals is usually not recycled. Meanwhile, building materials stay in the economy for a long time and are usually not recycled at the end of their lifetimes. Our economy is entropic, rather than circular. Therefore even a non-growing economy would require fresh materials from the commodity frontiers. This is independent of whether economic policies are neo-liberal, national-populist or Keynesian-social-democratic. Hence the powerful support by Latin American EJOs to new doctrines of post-extractivism that have emerged because extraction of minerals, fossil fuels or biomass at the commodity frontiers causes terrible socio-environmental damage (Arana 2013; Svampa 2012).

Climate change arises from the excessive production of carbon dioxide and other gases, which is a form of waste. A term from the EJOs that has been successful in the struggles against both ecologically unequal trade and climate change is the ecological debt (Figure 3). In a survey, Warlenius et al. (2013) explain:

At least two reports on ecological debt were published in 1992: Deuda ecológica (Robleto and Marcelo 1992) and Miljöskulden (Jernelöv 1992). The authors of these reports, from Chile and Sweden respectively, were most likely unaware of each other and their reports are quite different in approach and content. The former was an intervention into the global environmental negotiations going on in Rio at the time from a critical NGO, while the latter was a report written for the Swedish Environmental Advisory Council and intended for a national audience.

The first was on the intragenerational, the second was about the intergenerational ecological debt.

\footnotetext{
${ }^{11}$ Maxime Combes from ATTAC, France, and other "fracktivists" have published blog entries in the EJOLT project in 2012-13, as follows: http://www.ejolt.org/2012/09/global-frackdown-on-fracking-companies/ http://www.ejolt.org/2013/06/fracking-activists-occupy-chevron-in-poland/ http://www.ejolt.org/2012/02/shale-gas-fracking-in-bulgaria-freezes-under-public-pressure/ http://www.ejolt.org/2013/10/fracking-under-fire-from-canada-to-romania/
} 


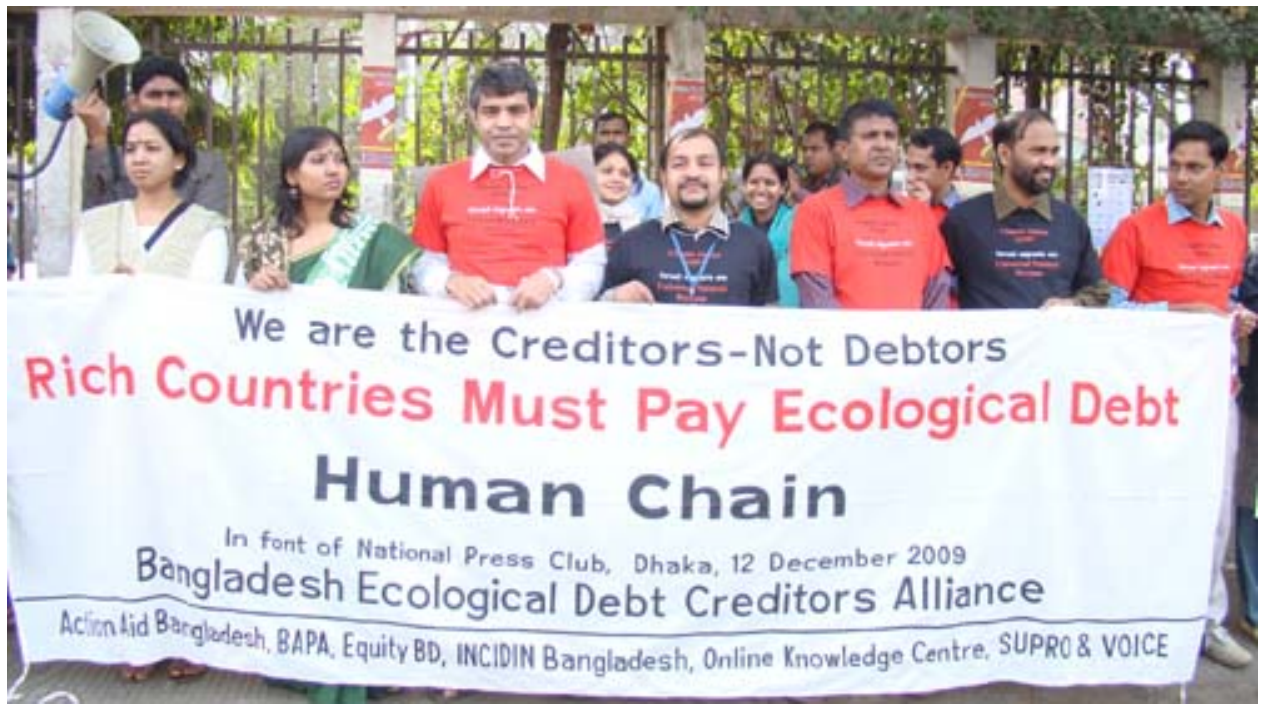

Figure 3. Ecological debt: the Bangladesh Ecological Debt Creditors Alliance demonstrating on Global Ecological Debt day, December, 12, 2009. Source: Equity and Justice Bangladesh Working Group (www.equitybd.org)

There was an alternative treaty signed in Rio de Janeiro in 1992 on the ecological debt from North to South. A Colombian lawyer, J.M. Borrero, published a book on the Ecological Debt (Borrero 1994). The Ecuadorian EJO Acción Ecológica took up the term, and the struggle, in 1997, with several publications which included a definition and many examples. According to Acción Ecológica, the ecological debt arises from the plunder of resources (ecologically unequal trade) and also from the occupation by rich countries of disproportionate 'environmental space' (a term coined by academics - Weterings and Opschoor 1994- but popularized by civil society) to dump excessive amounts of carbon dioxide in the oceans and the atmosphere which belong to all humans equally (Martinez-Alier 2002). Some governments from countries of the South have also deployed the concept of ecological debt (or one part of it, the climate debt) in international negotiations on climate change. In the COP in Copenhagen in 2009, over 30 heads of government or ministers mentioned the ecological debt in their speeches provoking the irritation of US Ambassador Todd Stern. A few months later, economist Jagdish Bhagwati (2010) argued, against Todd Stern, that a principle of "strict liability" should indeed be operative in climate change in proportion to accumulated past emissions by country.

The origin of the concept of ecological debt and many of the theoretical developments around this concept are rooted in Latin American EJOs, the international Friends of the Earth and Jubilee South and other Christian movements (Simms et al. 1999). Academics joined in later by conducting calculations and publishing articles and books on the term (Paredis et al. 2004, 2008; Simms 2005, 2009; Srinivasan et al. 2008). While these and other academics (Rice 2009) gave support to the concept of ecological debt, energy economist Olivier Godard (2012) blames its defenders for the abject failure of international climate change policy from Copenhagen in 2009 to Doha 2012. ${ }^{12}$ Instead of acknowledging that an international agreement needs to face up to the distributional obstacles, and that this has not been done (Martinez-Alier 1993).

Some activists have looked at ecological debts inside a single state, caused by internal colonialism and extractivism. Thus, calculations have been made of the ecological debt to the state of Odisha in India (Peralta 2006). Other activists decided to use ecological debt (rather than the term environmental liability) for the

\footnotetext{
12 http://globalgovernanceprogramme.eui.eu/ecological-debt-and-historical-responsibility-revisited-the-case-of-climatechange
} 
unpaid socio-environmental damages from particular firms. ${ }^{13}$ K.W. Kapp had written much earlier that capitalism is in essence an economy of unpaid social costs (Kapp 1950).

Unsurprisingly, it was also EJOs that introduced and developed the concept of climate justice. Patrick Bond, a former student of David Harvey and active as a member of the Durban Group for Climate Justice, explains that the term emerged during the early 2000s, and rapidly spread around the world (Bond 2010, 2014). By 2007 even Angela Merkel was naming it as basis for a future global climate policy, and for the very ambitious German targets for greenhouse gas emissions (minus 90-95\% by 2050). According to Bond, the US environmental justice movement had generated a core lineage in 1980s-1990s of anti-racist environmentalism which conclusively linked social justice to geographically located ecological problems and transcended 'Not in My Backyard' (NIMBY) arguments in favor of a system-transforming narrative. Then in the 1990s came global-scale demands to recognize the ecological debt owed by the North to the South, made by groups such as Acción Ecológica, as well as wider-ranging considerations of climate, leading up to alternative proposals at the Kyoto Protocol negotiations of 1997 such as a moratorium on new oil exploration in sensitive areas (Bond 2014).

Also very influential was the CSE (India) booklet of 1991, Global warming: a case of environmental colonialism authored by Anil Agarwal and Sunita Narain (1991) pointing out that there were "subsistence carbon dioxide emissions" vs. "luxury carbon dioxide emissions" (an idea taken up by Shue 1994). Then in the late 1990s came the Jubilee campaign against Northern financial bullying of the South, comparing the large ecological debt from North to South to the financial debt from South to North. The concept of climate debt was supported by the World Council of Churches (Peralta 2006) and other groups (Christian Aid, 2009). According to Bond (2014), the 2000s global justice movement also came to the fore with the December 1999 Seattle WTO protest and challenged corporations and multilateral institutions with greater force than in prior years.

Turning specifically to Climate Justice, a 2000 event in The Hague sponsored by the New York group CorpWatch was the first known conference based on this term. CorpWatch had published a document in November 1999 authored by Kenny Bruno, Joshua Karliner and China Brotsky:

Climate Justice means, first of all, removing the causes of global warming and allowing the Earth to continue to nourish our lives and those of all living beings. This entails radically reducing emissions of carbon dioxide and other greenhouse gases. Climate Justice means opposing destruction wreaked by the Greenhouse Gangsters at every step of the production and distribution process -- from a moratorium on new oil exploration, to stopping the poisoning of communities by refinery emissions -- from drastic domestic reductions in auto emissions, to the promotion of efficient and effective public transportation (Bruno et al. 1999).

Four years later, the 'Durban Group for Climate Justice' was launched, and remains an important strategic listserv for those opposed to carbon trading and other false solutions to the climate crisis such as CDM projects (cf. Larry Lohman's critique of carbon trading ${ }^{14}$ ). The sometimes inchoate advocacy movement known as 'Climate Justice Now!' began in 2007, and played a role in grassroots advocacy as well as at global-scale UN climate summits. The highest-profile of these, with 100,000 protesters demanding a strong agreement from negotiators, was in Copenhagen in 2009 (Figure 4). Europeans had formed a Climate Justice Alliance (CJA) whose 'Reclaiming Power' protest was repressed by the Copenhagen police. A network on climate justice had been formed at COP 15 in Bali, 2007 (Roberts and Parks, 2007, 2009). The Third World Network from Penang (TWN 2009a,b, 2010) gave strong support to the notion of the ecological debt before Copenhagen.

\footnotetext{
13 http://www.ejolt.org/2013/01/is-umicore-really-the-most-sustainable-company-in-the-world. Also Meynen's and Sebastien's chapter in Healy et al. 2012.

14 http://www.dhf.uu.se/publications/development-dialogue/carbon-trading-a-critical-conversation-on-climate-changeprivatisation-and-power See also the EJOLT Report no. 2 for a critique of CDM cases in Africa (Bond et al.,2012).
} 

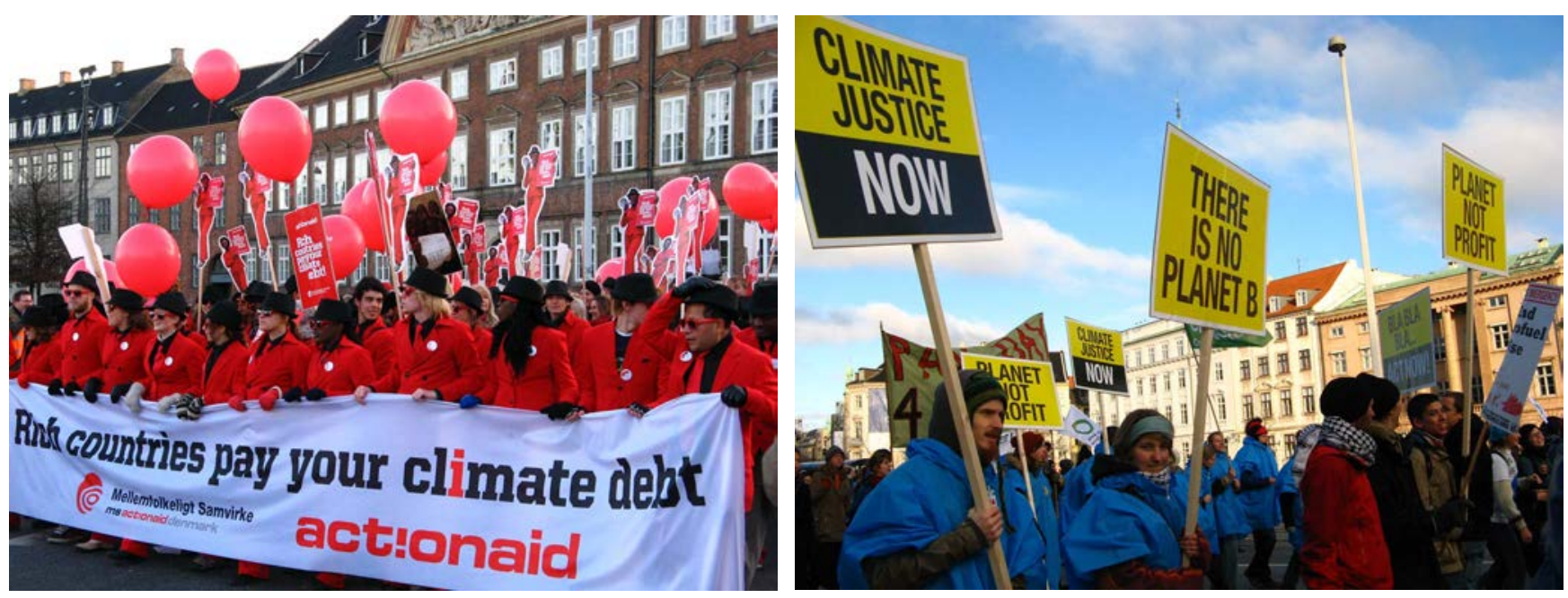

Figure 4: Climate debt: protesters for climate justice and for the repayment for the climate debt in Copenhagen, 2009. Source: niOS at Flickr.

Shortly after the failure of the Copenhagen summit, the Bolivian government led by Evo Morales and his then UN Ambassador Pablo Solon hosted a 2010 conference in Cochabamba, attended by 35,000 activists, including 10,000 from outside the country. Pablo Solon later lost his role as Ambassador to the UN and went back to civil society activism after 2011. The Cochabamba conference of 2010 adopted several demands that, as Patrick Bond explains (2014), were an anathema to mainstream UN climate politics:

- $\quad$ A 50 per cent reduction of greenhouse gas emissions by 2017

- Stabilizing temperature rises to $1^{\circ} \mathrm{C}$ and limiting greenhouse gas concentrations to 300 parts per million of $\mathrm{CO}_{2}$

- Acknowledging the climate debt owed by developed countries

- Full respect for human rights and the inherent rights of indigenous people

- Universal declaration of rights of Mother Earth to ensure harmony with nature

- Establishment of an International Court of Climate Justice; rejection of carbon markets and commodification of community indigenous forests through the REDD program

- Promotion of measures that would change the consumption patterns of developed countries

- Ending intellectual property rights for technologies useful for mitigating climate change

- Payment of 6 per cent of rich countries' GDP for addressing climate change.

Another initiative from civil society was led by activist author Bill McKibben of the United States, who in 1988 serialized and then published one of the first popular books on climate change (The End of Nature, McKibben 1989). In 2007 he started the 350.org movement, supported by top climate scientists such as James Hansen. 350.org has gained a large international following with national chapters and mass actions. They criticize extraction of fossil fuels, and members were arrested in 2013 in demonstrations at the White House against the Keystone XL pipeline. They criticize the European Union's politically expedient acceptance of a $450 \mathrm{ppm}$ threshold for atmospheric $\mathrm{CO}_{2}$ concentration.

\section{Biopiracy}

The ecological debt arises from two main causes, ecologically unequal trade and the disproportionate use of environmental space. While ecologically unequal trade is an academic concept that Hornborg (1998) helped to coin (with Altvater 1993; Bunker 1985; see Hornborg et al. 2007), one aspect of it had earlier been discovered and named by civil society. Biopiracy was the name given by Canadian activist Pat Mooney of 
RAFI in 1993, and popularized by Vandana Shiva drawing on her activist role in cases in India (Mooney 2000; Shiva 1997). It denotes the appropriation of genetic resources (in medicinal or agricultural plants) without any recognition of the original knowledge and property rights of indigenous peoples (Figure 5). The word 'biopiracy' has been used in many complaints by EJOs in the last twenty years. Academics writing in scientific journals and doctoral theses have also used the term (not always quoting the original source). Even state authorities in countries like Brazil have started to use it (Martinez-Alier 2012a). Examples of this type of biopiracy are indeed numerous throughout history and today (Robinson 2010). They include the appropriation of human genetic resources of indigenous peoples without previous and informed consent. Sometimes the resources in question, or some of their properties, have been patented.

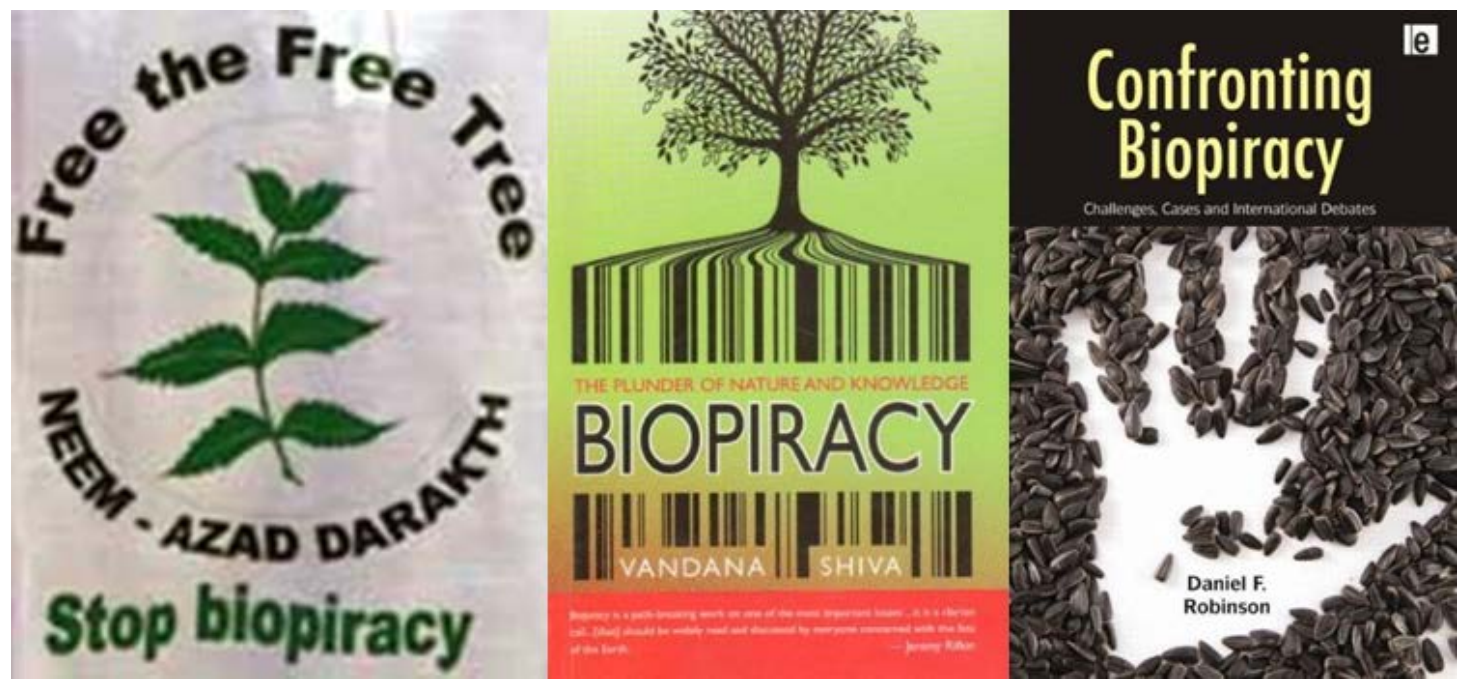

Figure 5: Biopiracy, from social activism to academic analysis. Source: Pictures from India Environment Portal, and cover pictures from Shiva (1997, edition 2012) and Robinson (2010).

\section{Water justice}

The terms water justice or hydric justice are associated with university professor Rutgerd Boelens at Wageningen University, but he has been working so closely with activists for many years that he himself would no doubt like water justice or hydric justice to be seen as EJO concepts (Boelens et al. 2011; Isch et al. 2012). The favourite slogans of this group of activist researchers are "water runs towards power" and "water runs towards money" - unless stopped by civil society movements.

The water justice concept has several dimensions, from water management models to asserting the Human Right to Water and Sanitation (as recognized by the UN General Assembly in July 2011). In the 2000s, the 2003 World Water Forum in Kyoto was one of the most important events for EJOs ${ }^{16}$; there was strong opposition against the pro-privatization World Water Council's claim that there was a "consensus" on a corporate-controlled future for water. Water was not seen as purely an issue for conservationists and environmentalists but as an all-encompassing and vital commodity. At the same meeting, the strong commitment of the Council of Canadians was a key element of an alliance among EJOs on water issues that issued its own 'Vision Statement', starting to build a movement under the slogan Water is Life. From there on, an Alternative World Water Forum (FAME, from the French acronym) has taken place in parallel to the official water forum, and in the same cities (Mexico 2006, Istanbul 2009, and Marseilles 2012), bringing together EJOs, advocacy groups, scholars, journalists, local activists and committees. It has been a watchdog on policies promoted by the World Bank, the EU and transnational corporations, as well as national governments. There is now a Water Movement at a global scale. It cooperates with some local governments and also with workers' unions in the public services in order to defend a public management model for water supply, and to profit from the technical skills and knowledge of workers. The network 'Reclaiming Public

\footnotetext{
${ }^{16}$ http://www.waterforum.jp/en/home/pages/index.php
} 
Water', established through the Transnational Institute, supports and backs efforts to bring water management back under public control. ${ }^{17}$

But Water Justice is not only about urban water management. In 2011, many pushed for the recognition of the Human Right to Water (HRW) at UN level. The work of Pablo Solon and Maude Barlow (among others) was crucial for this battle. Food and Water Watch, Red Vida at the pan-American level, and Focus on the Global South, Jubilee South, and the African Water Movement are working towards actions and tools for the concrete application of the HRW. An important actor is again the Council of Canadians' Blue Planet Project, a network working with grassroots struggles to protect democratic, community control of water and sanitation. There is also an activist-academic network for Latin America, called Waterlat.

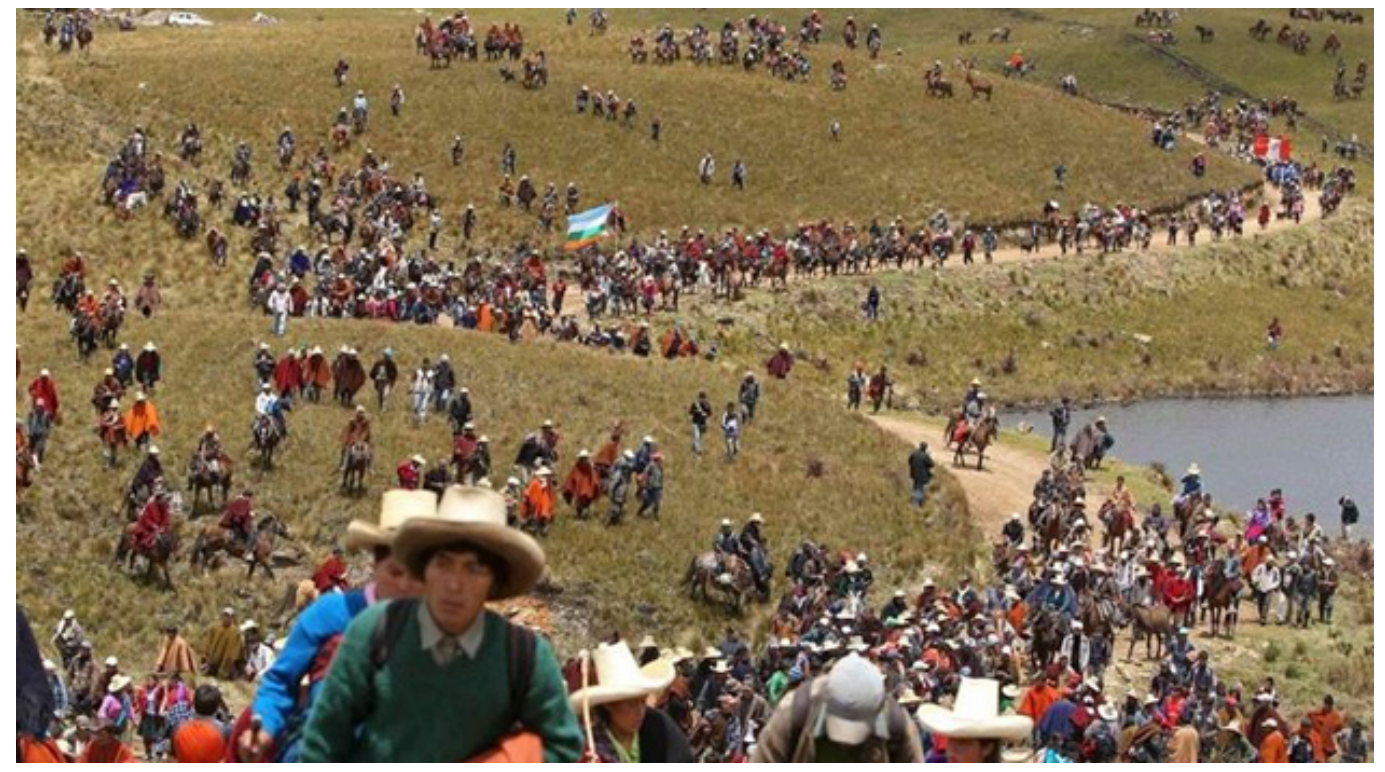

Figure 6: Water justice: The national march for water and for life (and against mining) from Conga, Cajamarca, included a Foro de Justicia Hídrica in Lima, Peru (January 2012). Source: Perumundo.

At the European level, the Italian referendum 2 Sí per l'Acqua Bene Comune in 2011 was a turning point. Defining water not merely as a good or as a service, the proponents of the referendum argued water be considered part of the commons, which cannot be treated as a mere service subject to monetary valuation. The debate has become very animated in Europe with the remunicipalization of water supply services in Paris by Eau de Paris, and in Naples with Aqua Bene Comune. On $10^{\text {th }}$ and $11^{\text {th }}$ December 2011, the European Water Movement was launched in Naples. In its Manifesto, more than privatization-related issues are addressed. It states that the movement aims to "reinforce the recognition of water as a commons and as a fundamental universal right, but also to take into account the health of ecosystems...". It is searching for strategies shared with the wider ecological movement. ${ }^{18}$

Water justice and commons have therefore become intertwined concepts, which cannot be separated. Such connections have been made by social movements in India with the slogan Jal-Jungle-Zamin. ${ }^{19}$

\footnotetext{
${ }_{17}$ The website www.waterjustice.org, born at the World Social Forum in Mumbai in 2004, provides a collective source of information while www.remunicipalisation.org offers a tracker tool for increasing visibility of such experiences.

${ }^{18}$ The Naples Manifesto is available at http://europeanwater.org/about-the-european-water-movement/naples-manifesto

${ }^{19}$ Interestingly, one main spokesman for the new party AAP in India, Yogendra Yadav, has said: "... the most creative energy in our public life has not come from within politics proper but from outside politics - from people's movements on issues such as displacement, Dalits, farmers, women, right to food, right to information and above all, jal, jungle, zameen (water, forests, land). The difficulty is that this energy did not have a political expression, hope, and a political vehicle. In my dream script, the AAP is the natural political hope for these energies". (24 Dec. 2013, http://www.thehindu.com/todays-paper/tp-opinion/tapping-the-transformative-energy/article5495629.ece).
} 
Management plans cannot artificially split them into different departments or state agencies. High waterimpact projects such as dams for hydropower or irrigation purposes, thermal power plants, mining, massive timber logging, Special Economic Zones, monocultures, and the interlinking of rivers need to be analyzed in a comprehensive way with consideration to social justice, entitlements and fair redistribution. As regards dams, canals, and hydropower plants, more and more groups are talking about the grabbing of land and water as inseparable. National networks such as the MAB in Brazil (movimento dos atingidos por barragens) have arisen in many countries. MAB is particularly advanced also in term of alternative practices related to energy sovereignty and the democratization of energy production and consumption. The International Rivers Network has provided much information and support to such anti-dam movements (McCully 1996).

The World Commission on Dams was a civil society initiative that reported its conclusions in 2000 (WCD 2000). Among its members were representatives of business and of the World Bank, and also of conservationist organizations. It arose because of the strength of resistance movements against dams, the most visible at the time being the Narmada Bachao Andolan in India, where Medha Patkar's campaigns have been influential. The WCD's conclusions went directly against much of the previous literature in favor of dams, and also against the cost-benefit analysis procedures for deciding on dam building. The WCD report was sensitive to non-monetary valuation, finding that large dams provide important water and power supply services, but that the social and environmental sacrifices that they impose are often unacceptable. The WCD estimated that large dams had already displaced 40 to 80 million people, and that many of these people were impoverished by the process. However, its recommendations have not been implemented. ${ }^{20}$

Anti-dam movements continue to denounce water enclosures along with forced acquisition of land, diversion of rivers, and dispossession and displacement of rural and indigenous communities that inhabit territories rich in biodiversity and water sources. They include the Brazilian MAB (Movement of People Affected by Dams) and the struggle against the diversion of the San Francisco river in Brazil's northeast, the MAPDER network (Mexican Movement of People Affected by Dams) in Mexico, the campaign to save the ancient city of Hasankeyf from the Ilısu Dam in Turkey (and to support Kurdish rights), the Patagonia Sin Represas and Ríos Vivos campaigns in Latin America, and numerous complaints from the Mekong riverine communities in Southeast Asia. All are examples of articulated opposition movements to large and destructive dam projects.

Movements for water justice have learnt to use metrics developed in academia (virtual water, water footprint) and also concepts such as minimum ecological flow. In Spain, in the struggles against inter-basin water transfers, a new term appeared around 2000; the new water culture (nueva cultura del agua) which became a successful political slogan. It rooted itself in the European Water Framework Directive to emphasize that water reaching the sea was not wasted. In India, confronted with the fact that the Ganga and its tributaries were being dammed in Uttarakhand, the director of the CSE, Sunita Narain, was reported to be asking for a minimum ecological flow of 50 percent in the winter season for all river systems before the monsoon. ${ }^{21}$

The water issue has also entered the top priority list for groups working against the financialization of nature and environmental services. ${ }^{22}$ Antonio Tricarico from the organisation Re:Common wrote that this financial capitalist approach:

...goes far beyond the current privatization of water services and utilities and would require a significant increase in the production of fresh water through desalinisation, purification and so on, as well as the storage, shipping and transportation of water through a new network of dams and large-scale canal systems to connect different water basins. Such a set-up is needed to create 'large water trading', meaning the process of buying and selling water access entitlements... ${ }^{23}$

\footnotetext{
${ }^{20}$ http://www.internationalrivers.org/campaigns/the-world-commission-on-dams

${ }^{21} \mathrm{http}$ ://timesofindia.indiatimes.com/home/environment/developmental-issues/Dams-may-dry-up-Ganga-warnsministerial-group/articleshow/19485134.cms

${ }^{22}$ See for example the video "Financialization of Nature" produced by SOMO, Food \& Water Europe, Friends of Earth, Carbon Trade Watch, WEED, Ecologistas en Acción, Aitec and others at http://vimeo.com/43398910

${ }^{23}$ http://www.un-ngls.org/gsp/docs/Financialisation_natural_resources_draft_2.pdf
} 
Groups denouncing the financialization of nature held various meetings at the FAME in Marseilles ${ }^{24}$, at Rio+20, and at the 2013 World Social Forum in Tunis. They warn against the growing commodification of natural resources and environmental services (beyond water) to provide a new sphere of accumulation for capitalism through new financial assets. ${ }^{25}$

\section{The defence of the commons}

The Guerra del Agua (the 'water war') in Cochabamba, Bolivia in April 2000 has stayed in the memory of water justice activists; the population of this Bolivian city took the control of the municipal water supply system after violent riots against corporate control; the companies Bechtel, Edison and Abengoa had to leave and civil society regained control over the resource. The international Water Movement has drawn lessons from this, and it has managed to link the issue of water management control with democracy and the commons, now linked concepts.

A new term is gaining strength in recent years in EJ struggles, The Commons Movement (c.2008). The commons are seen as a crucial sector of the economy that must be defended to preserve de-commodified access to food, water, housing, forests, clean air (and also to public goods, like the internet). Warnings against commodification can be traced back to the young Karl Marx's critique of forest privatization in the Rhineland that prevented poor people from obtaining fuelwood and non-timber products. EJOs defend the commons. They dislike Hardin's (1968) account of the "tragedy of the commons" (which conflated "open access" with commons), and they fight against the reverse, the "tragedy of enclosures" (Martinez-Alier 2002). EJOs do quite often praise the work of Nobel economics laureate Elinor Ostrom, who collected and explained cases of well-functioning commons (Ostrom 1990).

The defence of the commons is nevertheless an old notion going back intellectually at least to Karl Polanyi, E.P. Thompson (The moral economy of the crowd, 1971), and in South America to Florencia Mallon's The defence of community in Peru's central highlands (1983). Revolutionary agrarian and indigenous movements have defended the commons, in Mexico in the early 1900s inspired by Emiliano Zapata, and again in Bolivia in 1952. ${ }^{26}$ In Eastern Europe and Russia, aspiring to a socialism based on peasant communes goes back to the narodniki in the 1870s to the 1920s. Their slogan "Land and Freedom" was taken up in Mexico and is today used in Peru (Tierra y Libertad, which could more properly be Tierra, Agua y Libertad).

The defence of the commons has a long history in many countries, with different social and political protagonists. Thus, in Britain, the "This Land is Ours" movement (in which the now well-known environmental journalist George Monbiot was involved), was a commons movement begun in the 1990s with a high profile land occupation of the Wandsworth brewery site in London, destined for expensive commercial development. $^{27}$ Some centuries before, Britain had seen many acts of resistance defending the commons against enclosures, possibly going back to Gerrard Winstanly's Diggers of the mid $17^{\text {th }}$ century. Much later, around 1900, a more urban type of movement was present in Olivia Hill's campaign against development of suburban woodlands in London, helping to save Hampstead Heath. She was one of the founders of the National Trust, identified with middle or upper class support. It was established to preserve places of historic interest or natural beauty. Similar accounts of pro-commons movements, largely before an environmental discourse was present, could be produced for many countries.

\footnotetext{
${ }^{24}$ http://www.fame2012.org/en/2012/02/26/climate-and-financialization/

${ }^{25}$ UN support for Payment for Ecosystem Services (PES) as pushed by the UNEP project TEEB (2008-2011), The Economics of Ecosystems and Biodiversity, is part of this trend.

${ }^{26}$ To understand today's zapatismos from a political ecology viewpoint, see Víctor Toledo's articles in La Jornada, Feb. 2013. http://www.jornada.unam.mx/2013/02/01/opinion/028a1pol and http://www.jornada.unam.mx/2013/02/15/opinion/024a1pol

${ }^{27}$ http://www.tlio.org.uk, http://www.tlio.org.uk/campaigns/wandsworth/puremonb.html
} 
Today, Massimo De Angelis and Antonio Negri (Hardt and Negri 2009) have been important touchstones for defence of the commons, inspiring some activists. ${ }^{28}$ Their approaches avoid elucidating a specific environment discourse, are not really connected to the global EJ movement, and do not discuss "social metabolism", the "...manner in which human societies organize their growing exchanges of energy and materials with the environment" (Martinez-Alier et al. 2010: 153; Fischer-Kowalski and Haberl 1997).

\section{Biomass conflicts}

A range of EJO concepts and policies have been borne of environmental injustices related to biomass. Complaints against eucalyptus, acacia, and gmelina tree plantations for wood or paper pulp that deprive local people of land and water, gave rise twenty years ago to the slogan and movement "Plantations are not forests" (Carrere and Lohman 1996; Overbeek et al. 2012). The World Rainforest Movement collects and spreads information on plantation conflicts and proposes a change in the FAO definition of forest, to exclude tree monocultures, which are more properly called green deserts. ${ }^{29}$ The term green desert has its origins in Brazil, where local communities used it to refer to eucalyptus monocultures. In 1999, together with civil society organizations they formed a network that carried the term in its name: Rede Alerta contra o Deserto Verde. The term is now used by activists and sympathetic researchers to refer to any tree plantation (Emanuelli et al. 2009; FASE and TNI 2003).

In a related development, in the 2000s the global environmental justice movement refused to use the environmentally benign sounding term "biofuels" for biomass based fuel production. At the World Forum on Food Sovereignty held in Mali in March 2007 representatives of rural movements, womens' movements, fisherfolk, shepherds, environmentalists and scientists reached a consensus on this, and instead use the word "agrofuels" because the prefix "bio" was totally out of place with its positive connotations. ${ }^{30}$ The ETC group, founded by Pat Mooney and formerly called RAFI, the GRAIN (Genetic Resources Action International, a small international EJO and think tank) and Friends of the Earth activists, also expose the term "bioeconomy" as window dressing. (ETC also criticizes "geoengineering" experiments). ${ }^{31}$

Food sovereignty was introduced by Via Campesina, an international movement of farmers, peasants and landless workers, at the World Food Summit in 1996 (GRAIN 2005). As Via Campesina defines it, "food sovereignty" is the right of peoples to healthy and culturally appropriate food produced through sustainable methods, and their right to define their own food and agricultural systems. It develops a model of small scale sustainable production benefiting women, communities and their environment. It puts the aspirations, needs and livelihoods of those who produce, distribute and consume food at the heart of food systems and policies rather than the demands of markets and corporations that have come to dominate the global food system. ${ }^{32}$ The concept has been embraced by a broad range of social actors and organizations that raise their voices against GMO crops and "biopiracy", and in favour of peasant agriculture and "farmers' rights to save, exchange, and breed seeds and crop varieties" (McAfee 2008; GRAIN 2005). Moreover, the concept has come to be recognized by the UN Special Rapporteur on the right to food, Oliver de Schutter (2012). ${ }^{33}$ In this way food sovereignty goes far beyond the older concept of food security, by emphasizing self-determination. Thus in Mexico, a centre of origin for maize cultivation, there has been a strong movement under the name En Defensa del Maiz in support of peasant agriculture and against imported or Mexican-grown transgenic maize that threatens and "contaminates" the local varieties. Sin maiz, no hay país - they say. No maize, no country.

In Brazil in the struggle against the use of pesticides in monocultures, the concept of agro-toxics (instead of pesticides) was introduced by environmentalists with such success that it was officially

\footnotetext{
${ }^{28}$ Massimo de Angelis authored The beginning of history: value struggles and global capital (2007) and he is editor of The Commoner http://www.commoner.org.uk while Antonio Negri's work is in In praise of the common: a conversation on philosophy and politics with C. Casarino (2008) and Commonwealth with M. Hardt (Hardt and Negri 2009).

${ }^{29} \mathrm{http}: / /$ pulpinc.wordpress.com/2008/09/23/wrm-tells-fao-that-plantations-are-not-forests/

${ }^{30} \mathrm{http}$ ://www.grain.org/es/article/entries/607-latin-america-joao-pedro-stedile

31 http://www.ejolt.org/2013/01/geoengineering-conflicts-the-etc-map

32 http://viacampesina.org/en/index.php/organisation-mainmenu-44 (accessed March 28th, 2013)

33 http://lapress.org/articles.asp?art=6630 (accessed March 28th, 2013)
} 
acknowledged by the government in a national law in 1989 highlighting the importance of related health and environmental problems. ${ }^{34}$

GRAIN (already active in the 1980s and 1990s in the fight against agricultural biopiracy) introduced the term land-grabbing to describe a new, brutal wave of land acquisitions in Southern countries, largely for new plantations for export crops (Figure 7). ${ }^{35}$ GRAIN also published the first statistics on land-grabbing. The World Bank is trying to find a less aggressive term, for instance "land acquisition" and even "land sharing" while academics (including the editors of the Journal of Peasant Studies, and a team at the Institute for Environment and Development, IIED) sponsor conferences, publications and special issues. Meanwhile, a new policy against climate change was deployed by GRAIN and Via Campesina from about 2006, summarized in the slogan "Peasant agriculture cools down the Earth" (Martinez-Alier 2011) (Figure 8). All such concepts have given rise to large waves of academic research, but they were largely developed outside the universities and research institutes.

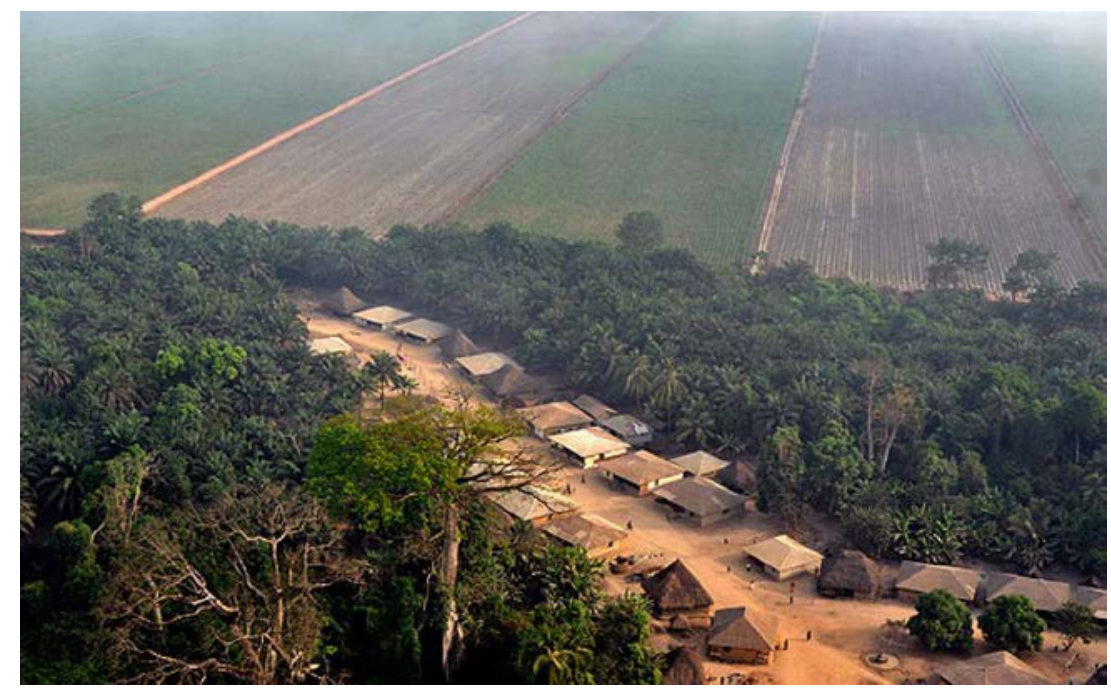

Figure 7: Land grabbing. Land taken by Addax Bioenergy for its sugar cane plantation in Sierra Leone. Source: Le Temps, cited by GRAIN (www.grain.org)

Some authors prefer the broad term, land conflicts but the specific concepts analyzed in this section (including land grabbing conflicts) arise from injustices in the appropriation of biomass. Not all land grabbing concepts are about biomass. For instance, there is land grabbing for price or rental speculation, in urban situations and related to public works. But the largest wave of land grabbing in many countries has to do with crops, pastures and tree plantations. These are different from mining or dam conflicts, or from conflicts over the use of urban space.

For instance, some international EJ networks such as Mines and Communities were borne from conflicts on mining; in Latin America, the very active OCMAL (Observatorio de Conflictos Mineros de América Latina) and the listserv No a la Mina (from Esquel, Argentina). They are not focused on biomass conflicts and land grabbing but on struggles against open cast mining (therefore including 'byproducts' such as water conflicts, soil pollution problems and land use conflicts generated by mining). Marine conflicts between industrial trawlers and artisanal fishermen take place offshore, and they are also biomass conflicts. In the EJOLT project we keep social metabolism and commodity chains (from resource extraction to transport to waste disposal) as the guiding threads of our work. So, a conflict over coal or copper mining is classified under the commodity in question, although it is also likely to also be a conflict over access to water rights and land appropriation.

\footnotetext{
${ }^{34}$ Law No. 7802 of 11 July 1989.

${ }^{35}$ http://www.grain.org/article/entries/4479-grain-releases-data-set-with-over-400-global-land-grabs
} 


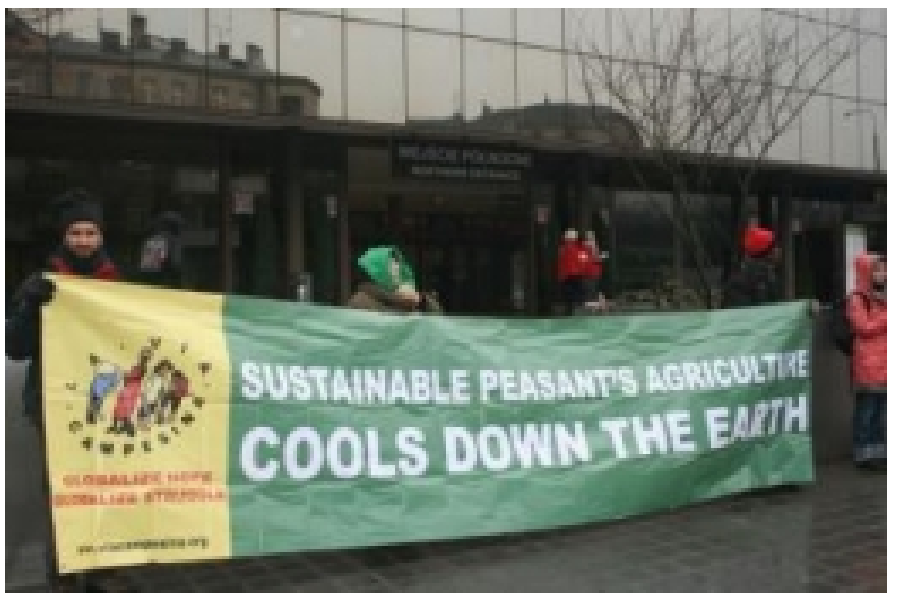

Figure 8: Peasant agriculture cools down the earth: La Vía Campesina demonstrates at the Poznań Climate Change Conference, December 2008. Source: Kooperative GartenCoop Freiburg (www.gartencoop.org).

\section{A note on "extractivism"}

The word extractivism as used by Eduardo Gudynas (researcher at the civil society organization CLAES, the Latin American Centre of Social Ecology in Uruguay) and Alberto Acosta (researcher at FLACSO, Ecuador and former Minister for Energy and Mining) refers to the excessive exploitation of exhaustible resources, or also of renewable resources (wood, fisheries, fertile soil). In Latin America, both "neo-lib" and "nac-pop" presidents - respectively, Sebastián Piñera and Juan Manuel Santos (neo-lib) or Rafael Correa and Cristina Fernández and even Pepe Mujica (nac-pop), favour extractivist export economies, and are criticized for it. ${ }^{36}$ Partisans of EJ tend to dwell on the various aspect of the "resource curse" that excessive exploitation indicates. There are two varieties of extractivism, compensatory- redistributive, and neoliberal (Gudynas 2012). A move to post-extractivism means a transition to a permanent or sustainable economy based on solar energy and renewable materials. This could be facilitated by quotas and taxes on raw materials exports.

There is need for clarification here, because the Brazilian struggles against deforestation in Amazonia from the time of Chico Mendes in the 1980s, gave a different meaning to the term extractivist reserves. They were used in a positive sense (Burke 2012). Seeing that the conversion of forests into pastures for cattle increased so-called "production" (because something that was outside the market was brought into the market), the rubber tappers (seringueiros, with anthropologist Mary Aleggretti) invented the new term, extractivist reserves, that acquired a legal meaning after Chico Mendes' assassination in Acre in December 1988. They denoted areas maintaining the standing forest, where the latex from the rubber trees and the harvested Brazil nuts (castanha do Pará) would be taken by local inhabitants for sale, and where small scale agriculture, fishing and hunting could be practiced for subsistence while other fruits and medicinal plants could be harvested sustainably. ${ }^{37} \mathrm{~A}$ few year later, the fact that the forests fulfilled other ecological functions (water recycling, carbon absorption) became common knowledge and gave further evidence to support socalled extractivist reserves demarcated by law.

This policy has not stopped the deforestation of Amazonia. Many people who try to keep the forests intact have been killed. In a repeat of the Xapurí assassination of Chico Mendes, in 2011 two known activists defending an "extractive reserve" in Pará (José Cláudio Ribeiro da Silva and Maria do Espírito Santo) were killed near their home in Nova Ipixuna, fifty kilometers from Marabá. ${ }^{38}$ Note the two (and opposite) meanings of extractivism. Some of the big mining and hydroelectric investments in Brazil under presidents

\footnotetext{
${ }^{36}$ http://triplecrisis.com/marx-and-president-correas-extraction/

37 On the role of Mary Allegretti as an 'action-researcher', see the interview with her by Adriano Belisário in 2009 in http://www.revistadehistoria.com.br/secao/gente-da-historia/chico-mendes-vivo-latex

${ }^{38}$ Felipe Milanez, http://www.ejolt.org/2013/04/cruelty-and-impunity-in-the-amazon
} 
Lula and Rousseff (such as the Belo Monte dam) epitomize Latin American extractivism, threatening some of the so-called extractivist reserves (in the Brazilian sense of the term).

\section{Territory}

In the EJOLT project, conflicts are classified according to the commodities in question; for instance, mining, biomass or oil and gas extraction conflicts. This is a socio-metabolic approach that includes resource extraction, transport, and also the conflicts over waste disposal at the end of the 'commodity chain.' Other classifications are possible, e.g. according to whether air or water pollution or soil contamination take place. It is clear that all ecological distribution conflicts necessarily take place in a territory - even ocean acidification or on changing rainfall patterns caused by climate change.

The notion of territory is deployed with special intensity in some conflicts. Indigenous communities have claimed territorial rights with ever growing intensity, and they have historically used the concept of territory to refer to the space in which they develop their physical, cultural, social, spiritual, political and economic lives. Indigenous and other rural communities have fought strongly for respect for the special and ancestral relationship they have to the spaces they have traditionally occupied. As part of their fight, they have claimed the international recognition of their right to territory. This right was finally recognized in the ILO (International Labour Organization) Convention 169 adopted in 1989 and ratified by a number of states, providing for "previous consultation" before there is exploitation of resources in the territory in question. Moreover, such rights have been recognised through regional human rights systems (for example the InterAmerican System for the Protection of Human Rights) and national constitutional systems. In other countries, indigenous people also have in theory a higher degree of protection, as is the case with the adivasi territories in India, even if the country is not a signatory of the Convention 169.

The concept of territory is not only used by indigenous populations but also by other communities who have a special relation with the spaces where they have historically lived in, for example, afrodescendants living in quilombos in Brazil or in palenques in Colombia ${ }^{39}$ or by peasant communities ethnically belonging to national majorities. One strategic use of this concept is to defend communitarian, collective properties instead of individual ones. In many urban struggles, as we shall see in the next section, the similar notion of "place" is very much present in the vocabulary of socio-environmental conflicts.

As the concept of territory denotes a special intensity of human-nature interactions, perhaps including sacredness of mountains or rivers, it has been central to some academic research on political ecology as illustrated by Arturo Escobar's work (Escobar 1998 and 2008). Sacredness is not commensurate with market values. For instance, if a forest in India is a "sacred grove" (an institution studied by Madhav Gadgil et al. 1976, 1993) it should be preserved. Money cannot buy something that is sacred. Notice that in India there are also "wildlife sanctuaries", an official (post-colonial) designation by the secular state that curiously seems to imply sacredness.

There are also National Parks and other areas excluded in principle from resource extraction. Exclusion from the market opens sometimes possibilities for collaboration between the Conservationist movement and the EJ movements defending indigenous territories and communitarian property. However, the mainstream international Conservationist movement is largely financed by the extractive industries, and it has been moving since Rio de Janeiro 1992 towards monetary valuation and payment for environmental services as the main policy instrument, distancing itself from the global EJ movement (Khan 2010).

\section{Transport, waste disposal and urban issues}

Traditionally, urban communities and the EJOs around them have denounced the disproportionate burden suffered by people of color and low-income communities in regards to toxic waste and other locally unwanted land uses. Recently, urban EJOs defending the role of recyclers of waste (against expropriation of waste by commercial firms and against incineration often disguised as "energy valorization") have argued that recycling helps against climate change. Unions of urban waste recyclers have gone to UN climate

39 For definitions of territory by indigenous, peasants and Afro-Colombian communities see http://www.pazdesdelabase.org/index.php?option=com_wrapper\&view=wrapper\&Itemid=253 (accessed April 2, 2013). 
change conferences as so-called cooling agents, supported by an international EJO called GAIA which is active against incineration of waste (Schindler et al. 2012). The representative of the union of recyclers of waste of Bogotá (Colombia), Nohra Padilla, was awarded a Goldman Prize in $2013 .{ }^{40}$ It is often claimed by NGO that zero urban domestic waste can be achieved.

There are some EJOs and networks - such as the Basel Action Network (BAN) fighting toxic colonialism or toxic imperialism or even toxic terrorism, namely the long-distance export of waste in various forms from rich to poor countries which in theory is forbidden by the Basel Treaty. Examples of such exports are ship-breaking in India or Bangladesh (Demaria 2010; and Demaria et al. 2012), chemical residues or nuclear waste, and electronic waste. ${ }^{41}$ The famous conflict over mercury exports to South Africa by Thor Chemical during the apartheid regime was linked to the birth of Groundwork, an EJO led by Bobby Peek, another recipient of a Goldman Environmental Prize.

In Nigeria, a well known case in the 1980s influenced the growth of the EJ movement that was to become so strong in the Niger Delta against Shell. This was the Koko dumping of illegal shipments of about 4000 tons of toxic waste from Italy in 1988:

The uproar this toxic-terrorism spurred reverberated in the national public discourse. The struggle for compensation and the eventual payment of N39.7 million (US\$250, 000) to the victims by the Nigerian Ports Authority, and the government's promulgation of Decree 42 on harmful waste [Special Criminal Provision] prohibiting the transportation, import, sale and trade of harmful waste in Nigeria was key in creating awareness and bringing environmental issues into the public domain (Ojo 2013).

Nigeria was not only the first African country to ratify the UN Basel Convention, but considerably influenced the text (Ojo 2013). There have been other documented similar cases in West Africa (e.g. waste dumping by Trafigura in Ivory Coast in 2006), giving rise to court cases. ${ }^{42}$

Industries make profits from waste, which EJOs denounce. The legal dumping of toxic waste in Warren County, North Carolina, in 1982 was the spark that ignited the self-conscious EJ movement. In Italy, and the Legambiente introduced the word Ecomafia to describe the corruption surrounding waste disposal in Campania and other areas, where there is a flourishing industry charging business and municipalities for waste disposal at reduced rates which become net profits because the waste is dumped illegally and without any treatment in caves, old mines or fields in mafia controlled territories (Armiero and D'Alisa 2012; Greyl et al. 2012; Massari 2003). ${ }^{43}$

The urban EJ agenda has become multi-faceted. In the transportation area, local groups in rich or poor cities demand cyclist and pedestrian rights (such as the cycle rickshaw drivers unions in India or the Critical Mass social movement in 300 cities of the world, mainly in the North). Critical Mass seems to have started in San Francisco around 1992 (Carlsson et al. 2012). A "critical mass" is defined as an "organised coincidence" of cyclists that periodically celebrate a collective bike ride in the streets; its purpose is to illustrate to society the great advantages that bicycles can provide to urban mobility (Figure 9). This is often backed by feminist arguments, since (middle age) men in many countries constitute the bulk of car users. In Germany, citizens' action groups (BBU) and Friends of the Earth (BUND) have demanded cyclist and pedestrian rights since the early 1980s. A network of NGOs and "green" institutes initiated by them emerged, and in 1990 Markus Hesse coined the term Verkehrswende (traffic turnaround) denoting a basic reorientation of planning priorities towards citizens' rights which is today commonplace political parlance. Typical municipal transport plans interpret this as equal shares for bicycles, trams/light rail and cars in non-pedestrian urban mobility.

\footnotetext{
${ }^{40}$ http://www.ejolt.org/2013/03/victory-for-waste-pickers. The issue of urban waste is Bogotá exploded politically in late 2013, when there was an attempt to remove left-wing mayor Gustavo Petro after he dismissed garbage collection contractors and tried to replace them by a city-run service based on recyclers' unions. Garbage accumulated in the streets because the former contractors did not provide transport in the transition phase.

41 On shipbreaking, there is an international network against this type of environmental injustice, http://www.shipbreakingplatform.org/off-the-beach-platform-2009-report

42 http://www.ejolt.org/2012/09/the-toxic-truth-about-trafigura-and-the-total-lack-of-environmental-justice

43 http://www.legambiente.it/contenuti/progetti-e-azioni/rapporto-ecomafia
} 
EJOs appeal to transit justice or transport justice - that is, the right to well-connected, affordable, and clean transit systems in cities (Agyeman and Evans, 2003; Loh and Eng, 2010; Loh and Sugerman-Brozan, 2002; Lucas, 2004). For instance, in the Bay Area in California, The Transit Riders for Public Transit (TRPT) Campaign protests against structural inequities in transport funding and investment which prioritize suburban expansion over the preservation of the existing system. In return, academics have examined spatial and social discrepancies in clean and affordable transport access, and pinpointed the variety of inequalities that are at the core of public transit in US cities - in terms of ridership, subsidy, security, and crowding (Soja, 2010).

On the other hand, numerous grassroots groups have raised complaints against controversial transportation of merchandise or passengers, and other large infrastructures. For instance, they have opposed the Keystone XL pipeline in the United States, the new railway line in Val de Susa in the No TAV movement in Italy, the Manta-Manaus project in Brazil, Peru and Ecuador, and the TIPNIS road in Bolivia. There is now a growing 'European Forum against Imposed and Useless Projects' (Grands Projets Inutiles et Imposés). In 2012 it held its 2nd meeting with 8,000 participants against the planned airport of Notre Dame-desLandes. This took place over five days in Brittany near Nantes from 7 to 11 July. The $3^{\text {rd }}$ Forum was held in summer 2013 in Stuttgart, the site of a resistance movement against a grand, new, superfluous train station. ${ }^{44}$ There are many other groups around the world complaining against damage by transport. One of great interest is Justiça nos trilhos (justice in the railways) in northern Brazil which itself is part of the Brazilian EJ movement, and at the same time a component of an international network complaining against the Vale mining company. The movement draws attention to the accidents, noise and pollution caused by the enormous iron ore exports transported by the railway from Carajás to the coast. ${ }^{45}$

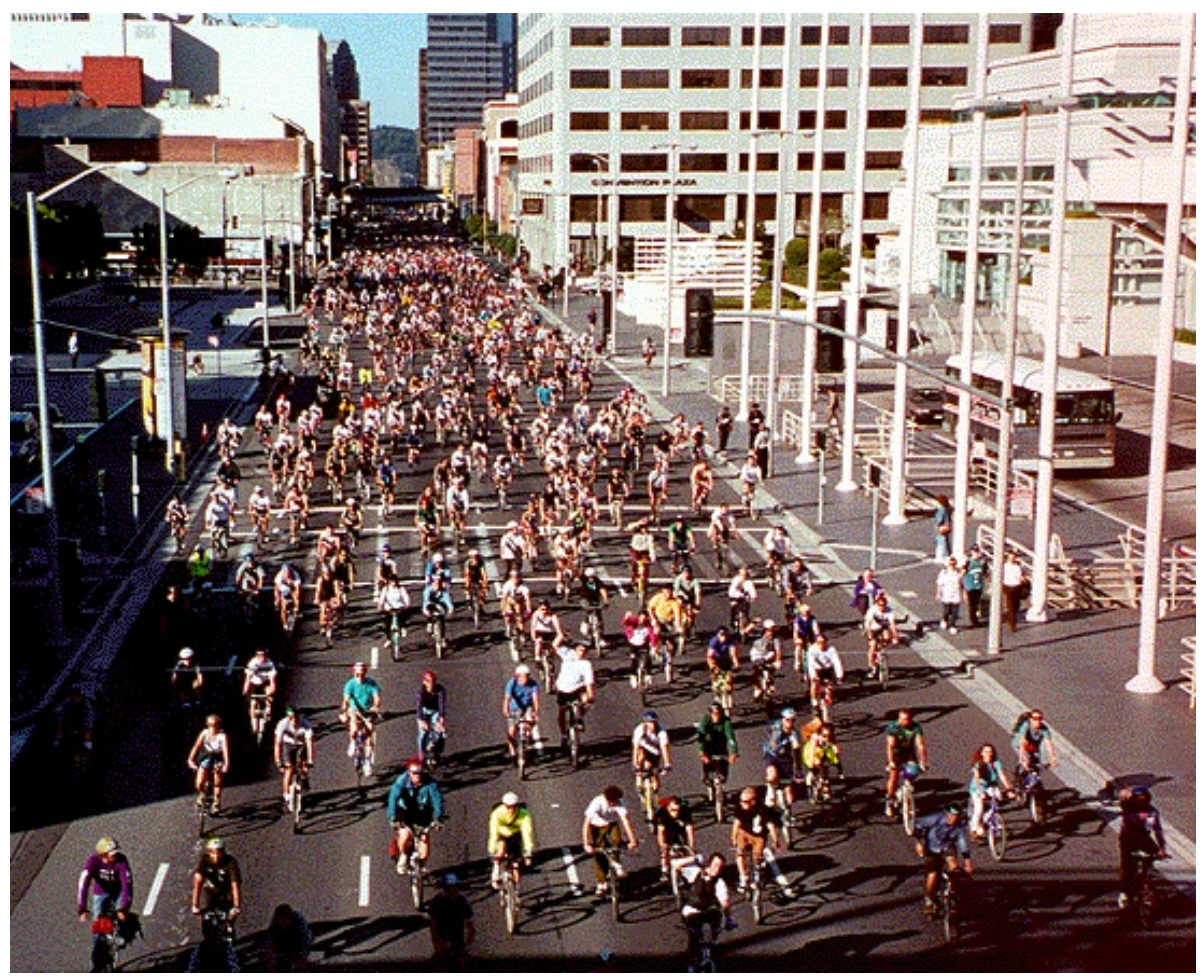

Figure 9: Critical mass ride in San Francisco, June 1996. Source: Chriss Carlsson at FoundSF.

\footnotetext{
${ }^{44}$ http://forum-gpii-2012-ndl.blogspot.com.es/2012 0701 archive.html (accessed 7 April 2013). http://intercoll.net/bdf/fr/questions/question-3.html. http://forum-gpii-2012-ndl.blogspot.com.es (accessed 18 April 2013). See also for instance, http://www.lagedefaire-lejournal.fr/la-carte-des-grands-projets-inutiles (accessed 11 January 2014).

${ }^{45}$ http://www.justicanostrilhos.org/quem-somos, www.atingidospelavale.wordpress.com
} 
Returning to urban issues, food supply in US cities has come to be a worrisome issue, with community advocacy centered around rights to healthy, fresh, local, and affordable food for low-income and vulnerable residents (Alkon and Agyeman 2011; Carney 2014; Gottlieb 2005; Gottlieb 2009; Gottlieb and Joshi 2010; Hess 2009). Organizations such as Growingpower in Milwaukee or Just Food in New York City mobilize residents around so-called food justice.

From Detroit to Chicago or Los Angeles, urban farms are sprouting to address food deserts and make culturally-valued food available to communities of color. The concept of food desert (Shaw 2014), which first emerged through studies conducted about retail availability in Scotland (Guy et al. 2004), has been widely used by EJ groups to denounce the scarcity of supermarkets and fresh food options in distressed urban communities. ${ }^{46}$ To denounce and address this urban scarcity, activists engage sometimes in guerrilla food gardening or take part in the many urban agriculture, permaculture and community gardening movements in cities around the world. Some urban organizations adopt the concept of food sovereignty as developed by Via Campesina, arguing for the right of urban growers to make decisions on their own about how and where food is produced and about the governance and planning dimensions of urban food systems. They reshape the relations between consumers, producers as well as public institutions that go beyond material and economic exchange and that contribute to a 'moralization' of food economies. In the context of these network initiatives the expression of food citizenship was coined (Renting et al. 2012).

Urban environmental justice is also connected (as we saw above, in the section on water justice) to struggles for the public management of utilities, for affordable water and electricity rates (with free minimum or lifeline allowances), and also to healthy, affordable housing with public green spaces. Demands include jobs and training for energy efficiency projects and funding or redistribution of revenues from utility companies for weatherizing residential homes (Anguelovski 2014; Fitzgerald 2010). Here, organizations talk about green justice, but overcoming "energy poverty" (Boardman 2009) has a significant component of social justice as well. This discussion has a potential to grow in countries with slums, and where urbanization projects may, in practice, evict poorer residents who are unable to afford the increasing costs of housing.

Residents and community organizations associate enhancing housing stock quality and increasing revenues for low-income and minority communities with initiatives meant to reduce carbon dioxide emissions and address climate change. For instance, in Massachusetts the Green Justice Energy Efficiency Campaign is defending the creation of small subsidies to allow low- and moderate income residents to weatherize the oldest and draftiest houses. Environmentalism here connects social equity, and new forms of asset creation, to sustainability (Agyeman and Evans 2003) and to climate change mitigation. Academic research centers, such as COLAB at MIT, support urban local organizations working on green justice, help them network with public officials, build their leadership skills, and assist them in grant applications to the US Department of Housing and Urban Development. There are also more radical urban movements, including squatters, that do energy and water audits and have theories on how a sustainable economy should function (Cattaneo 2011). The connections between urban ecology and social movements have been researched for some time (Di Chiro 1998). ${ }^{47}$

Land grabbing is also a concept that urban EJOs have started to use to denounce the speculative practices of developers, builders, and real estate investors in blighted neighborhoods that they attempt to turn around, thereby bringing in new residents and pushing for gentrification. There is also a strong connection between activists and researchers around the Right to the City. Several decades ago, French geographer Henri Lefebvre argued that this right is earned by taking part in the daily making of the urban fabric, by living in the city and by meeting particular responsibilities which entitle people to participate in decisions (Lefebvre 1968; Lefebvre 1972; Lefebvre et al. 1996; Mitchell 2003). People do not only control spaces of production, but use and shape the city. Cities are not meant to be for profit and developers, but for the people themselves.

\footnotetext{
${ }^{46}$ It could have been a resident in public housing in Scotland in the 1990s who coined the term. The extent to which "food" deserts exist and influence the diet outside the US is strongly debated. Anyway, poor hungry people in the world live in different kinds of "food deserts".

${ }^{47}$ Di Chiro's next book, Embodied ecologies: science, politics, and environmental justice, examines innovative coalitions combining environmental expertise and local environmental advocacy and connecting local, national and global processes.
} 
Today, coalitions such as the 'Right to the City Alliance'49 have emerged in the United States. In addition to demands for economic and environmental justice, coalition members ask for greater democracy in decision making related to urban planning, together with ending real estate speculation, community space privatization, and gentrification (Connolly and Steil 2009; Marcuse 2009).

In addition, struggles against "energy (and water) poverty" are not infrequent in urban areas in the South, as activists criticize the squandering of energy and water in luxury consumption or for subsidized exports. In South Africa's mining-energy-water complex, resistance movements have emerged. In Soweto (a suburb of Johannesburg, "South Western Township"), people denounce Eskom, the national electricity company, and question the behavior of public or private water companies that increase their rates and cut off supply to those who cannot afford them, while, at the same time, offering the cheapest electricity and water rates to mining companies as part and parcel of a policy of increasing primary exports (Sharife and Bond, 2012).

Also in the field of energy policy, since the 1970s civil society movements against nuclear energy have given rise to their own concepts. One of them, in Germany, was Energiewende (energy turn around) born in Whyl where in 1975 citizens occupied a construction site for nine months, founding there the "People's High School", discussing alternatives to nuclear energy based on a decentralization and democratization of renewable energy production and distribution. The nuclear plant was abandoned, and from the High School emerged the Ökoinstitut, which in 1980 summarized the concepts they developed in a study called Energiewende. Twenty years later, the term stimulated other "turn-around" concepts (i.e. radical changes of institutions and infrastructures) like the traffic turn-around (Verkehrswende) and the agricultural turn-around (Agrarwende) in the 1990s. A parallel term is used in 2013, Wachstumswende (growth turnaround), to translate the French décroissance or the English degrowth.

\section{The alliance between the Degrowth movement and the Environmental Justice movement}

Degrowth is a movement in some northern countries. It has not grown in universities, and not yet in EJOs, but rather in alternative urban or rural movements disengaging from the growth-led market economy. Degrowth is a slogan, a missile word (as Serge Latouche puts it, 2009). Latouche himself, an economic anthropologist, has long been a "post-development" thinker providing a link to Marcel Mauss, Karl Polanyi and Marshall Sahlins, and to continental thinkers of the 1970s to the 1990s like André Gorz, Ivan Illich, Cornelius Castoriadis, and Wolfgang Sachs (who criticized economic growth and also uniform development, together with Gustavo Esteva and Arturo Escobar in Latin America and Ashish Nandy and Shiv Visvanathan in India). The degrowers' intention is to spark a contentious debate on the future of our society.

Degrowth is based on grassroots projects such as food cooperatives, urban gardening, local currencies, co-housing projects, waste reduction and reuse initiatives, or the "transition towns" idea originating in the UK (Carlsson 2008; Chatterton and Pickerill 2010; Conill et al. 2012), essentially a bottom-up practical reincarnation of Local Agenda 21 projects of the 1990s sometimes going back to post-1968 neo-rural movements (like Sauvons le Larzac in France). Degrowth is based on localist projects, and proudly so. Practitioners believe, with ecofeminist economists (Waring 1988), that caring is more important for human welfare than commodity production - we have to safeguard the caring capacities of our societies as much as the carrying capacity of our environment. Degrowth activities allow for cooperation with local, regional and even national authorities, rather than relying heavily on governmental measures. They do not refrain from demanding national and supranational policy reversals.

Degrowth, launched as a movement by activists in 2001, quickly became an interpretative frame for a variegated social movement where several streams of critical ideas and political actions converge (Bayon et al. 2010; Bonaiuti 2011; Duverger 2011; Flipo 2007; Kempf 2007). It is an example of activist-led science now consolidating into proposals analyzed in articles and special issues of academic journals (Asara et al., 2013; Cattaneo et al. 2012; Demaria et al. 2013; Kallis et al. 2010, 2012; Martinez-Alier et al. 2011; Schneider et al. 2010, 2011; Sekulova et al. 2013). Supporting the Degrowth movement, there is also a new

\footnotetext{
${ }^{49}$ For more information, see http://www.righttothecity.org/our-history.html
} 
ecological macroeconomics without growth (Jackson 2011; Victor 2008), building upon Herman Daly's steady state economics of 1973, Georgescu-Roegen's "bioeconomics" (1971,1979), and the debates of the early 1970s and other literature on limits to growth (Meadows 1972, 2004; Odum 2001) with close links to social metabolic analyses mentioned earlier (EROI, material flows, carbon and water footprints).

Although not yet part of the global Environmental Justice movement, the Degrowth movement might enter into an alliance with southern EJOs (Martinez-Alier 2012b), for instance in its support for Resource Caps, a policy to reduce extraction of materials (distantly related to the Factor 4 and later Factor 10 concepts widely promoted by the Factor 10 Club in 1994, that rested on eco-efficiency improvements). Resource Caps are more closely related to the Yasunizing idea and to post-extractivist proposals in Latin America as put forward by Eduardo Gudynas (2012), Alberto Acosta (2013) and Maristella Svampa (2013). The Resource Cap Coalition brings together European organizations advocating a global resource use reduction, a precondition for sustainability. Outside Europe, local struggles against damage from mining (such as the ban on iron ore mining in Goa in 2012) have led to proposals for a resource cap. In this case, to reduce iron ore mining and exports from nearly 50 million tons per year to only 10 million tons. ${ }^{50}$ But resource use reductions, particularly in Southern countries, must be realized hand in hand with poverty reduction and building an ecological economy. In 2010 many organizations joined CEEweb's statement calling for resource caps to reduce total environmental pressure and to halt biodiversity loss. Several consultations took place which led to a common position calling for a 'European energy quota scheme' and the ratification of the Rimini protocol, a tool to cut back fossil fuel extraction (www.ceeweb.org/rcc). This is an ongoing process which builds on ideas put forward twenty years ago (Spangenberg 1995). While in the North there was the idea of reducing per capita consumption to the allowable world average, quantified in the reports from the Wuppertal Institute, an idea came from the South to create a línea de dignidad, a dignity floor as expressed by REDES (Uruguay) and the the IEP (Chile) at the time. This meant minimum free consumption allowances for all, a proposal also well known in South Africa and currently discussed in Europe. In 2014 the European Degrowth movement favors a universal "citizen's income" as a human right, expressed in monetary terms rather than in physical entitlements (Raventós 2007).

Degrowth is so far a small civil society movement with some political traction in France, Italy and Spain, and is gathering fans in other parts of Europe, North America and Australia. Its frequent conferences unite academics and activists. The next one in September 2014 will be in Leipzig under the banner of Wachstumswende. The movement argues that a democratic collective decision to consume and produce less in the global North is the most appropriate solution for the multiple crises facing the world today. We cannot get out of the debt crisis by economic growth, because this worsens the ecological crisis. The renouncing of economic growth by the North would help humanity to stay within the ecological limits of the planet as regards climate change, and would also contribute to a lower rate of biodiversity loss. The main allies for this new economy are the EJ movements of North and South.

Degrowth is therefore sympathetic to claims from the South for repayment of an ecological debt from North to South, and even more to the idea that this ecological debt should increase no further. Degrowth is against increases in the public and private financial debt, it pours scorn on the notion of "debt-fuelled growth", it favors much increased bank reserve requirements, and it promotes local currencies and ethical banking.

Proponents of degrowth in the North are natural allies of those in the South who champion the concept of buen vivir or Sumak Kawsay in Andean America (Acosta 2013; Acosta and Martínez 2009), Radical Ecological Democracy in India (Shrivastava and Kothari 2012), Ubuntu in southern Africa (Ramose 2002) or Mino Bimaadiziwin -'the good life' or 'continuous rebirth' in indigenous communities of Canada ${ }^{51}$, where the well-being of humans and the rest of the natural world are considered as interrelated and pursued at the same time. In India, the old Jain notion of sufficiency revived by Gandhians, aparigraha, expresses a moral principle against consumerism, and it is similar to the voluntary simplicity in the West born (we believe) in

\footnotetext{
${ }^{50}$ http://www.ejolt.org/2012/12/the-ban-on-iron-mining-in-goa

${ }^{51}$ This is a concept in the Canadian indigenous communities that re-emerged in 2012 with the struggle called Idle No More. See Naomi Klein's interview with Leanne Betasamosake Simpson; http://www.yesmagazine.org/peacejustice/dancing-the-world-into-being-a-conversation-with-idle-no-more-leanne-simpson
} 
the early 1980s. ${ }^{52}$ From ecological economics, Max-Neef's analysis of "needs" and "satisfactors" provides arguments to degrowers (Max-Neef and Kumar 1991). Meanwhile, there are struggles against large scale mining, land-grabbing, and fossil fuel extraction in many places in the South. Indigenous peoples are at the vanguard of such struggles. Despite traditional participatory exclusions (Agarwal 2001), women are often leaders in keeping sources of livelihood in the commons, also arguing in terms of indigenous territorial rights and human rights. Such movements complain at the same time against waste dumping from the North, including climate change caused by excessive carbon dioxide emissions.

Reducing consumption in the North would diminish demand for resources taken from valuable natural areas and allow increasing consumption of those so far deprived from it, without crossing environmental planetary boundaries. Indigenous victories to preserve homelands intact usually mean less pollution and biodiversity destruction from mining, fossil fuel extraction and big infrastructure projects and less of a push in the direction of disastrous climate change. The EJOs are potential allies of the groups in rich countries which criticize the obsession with GDP growth. The small degrowth movement in the global North is coming together with the strong EJ movements originating with poor or indigenous peoples from the South.

Leave oil in the soil (1997-2007) or Yasunizar (Acción Ecológica Ecuador, ERA Nigeria, and the Oilwatch network) is a proposal from EJOs in the South for not only leaving oil under the ground in areas of great biodiversity value and where indigenous territorial rights and other human rights are threatened (Figure 10). It is also a proposal for leaving "tar sands in the land, coal in the hole, shale gas under the grass", and also "offshore no more" after the huge BP oil spill in the Gulf of Mexico in 2010. This is in order to preserve nature, to combat climate change and to move to a post-fossil fuel civilization. In the North, megaprojects resulting in centralized supply structures empowering a few large companies have been rejected by proponents of the Energiewende with its democratization and decentralization impetus. The idea of leaving fossil fuels in the ground has been pushed by the civil society groups Carbon Tracker and New Economics Foundation in London (NEF) since 2011-2012 under the mottos unburnable oil, unburnable fossil fuels, unburnable carbon with such success that even The Economist (2013) explained in an article that to slow down climate change a large amount of reserves must be left in the ground, and therefore the economic valuation of such reserves (for instance, by pension funds buying shares in fossil fuel companies) was far too high.

To leave oil in the soil was not invented in London, however. The word yasunizar has the following origin. Ecuador proposed in 2007 (when Alberto Acosta was minister for Energy and Mining) to leave 850 million barrels of oil in the ground in the Yasuni ITT field - to respect indigenous rights, to keep biodiversity intact, and to avoid carbon emissions. The proposal implies avoiding carbon dioxide emissions of about 410 million tons from eventual oil burning, equivalent to France's emissions for one year. The original idea came from civil society. The government of Ecuador asked for partial outside compensation, US\$3,600 million roughly about one half of foregone revenues. A Trust Fund, under UNDP administration, was set up in August 2010. Investments would be used for energy transitions and social investments. This is an initiative to be imitated. Because of climate change, we cannot burn all the oil, gas and coal in the ground at the present rate. How to select the places where it is best to keep oil, gas or coal in the ground? The Niger Delta would certainly be one such place. ERA has long called for a moratorium on new oil exploration and exploitation in this region, and for an immediate end to gas flaring. ERA members sometimes say that the appropriate term should be ogonization, because Shell was expelled from Ogoni territory in Nigeria for many years after 1995. Other grassroots initiatives have called for leaving shale gas in the ground (in Quebec, the Karoo in South Africa, the Basque Country, France, Germany, Bulgaria) or leaving oil under the seabed (the Lofoten islands in Norway and in Lanzarote in the Canary Islands). In the mobilization against shale gas in many countries, a Global Frackdown day was held on the $22^{\text {nd }}$ of September, 2012. In France, ATTAC provided information and coordination to many citizens' groups against fracking (Temper et al. 2013).

\footnotetext{
${ }^{52}$ Australian philosopher and simplicity advocate Ted Trainer published an influential book, Abandon Affluence (1985), and has continued to support less affluent and simpler living (Batterbury 1996; http://simplicitycollective.com/therevolutionary-spirit-of-the-voluntary-simplicity-movement).
} 


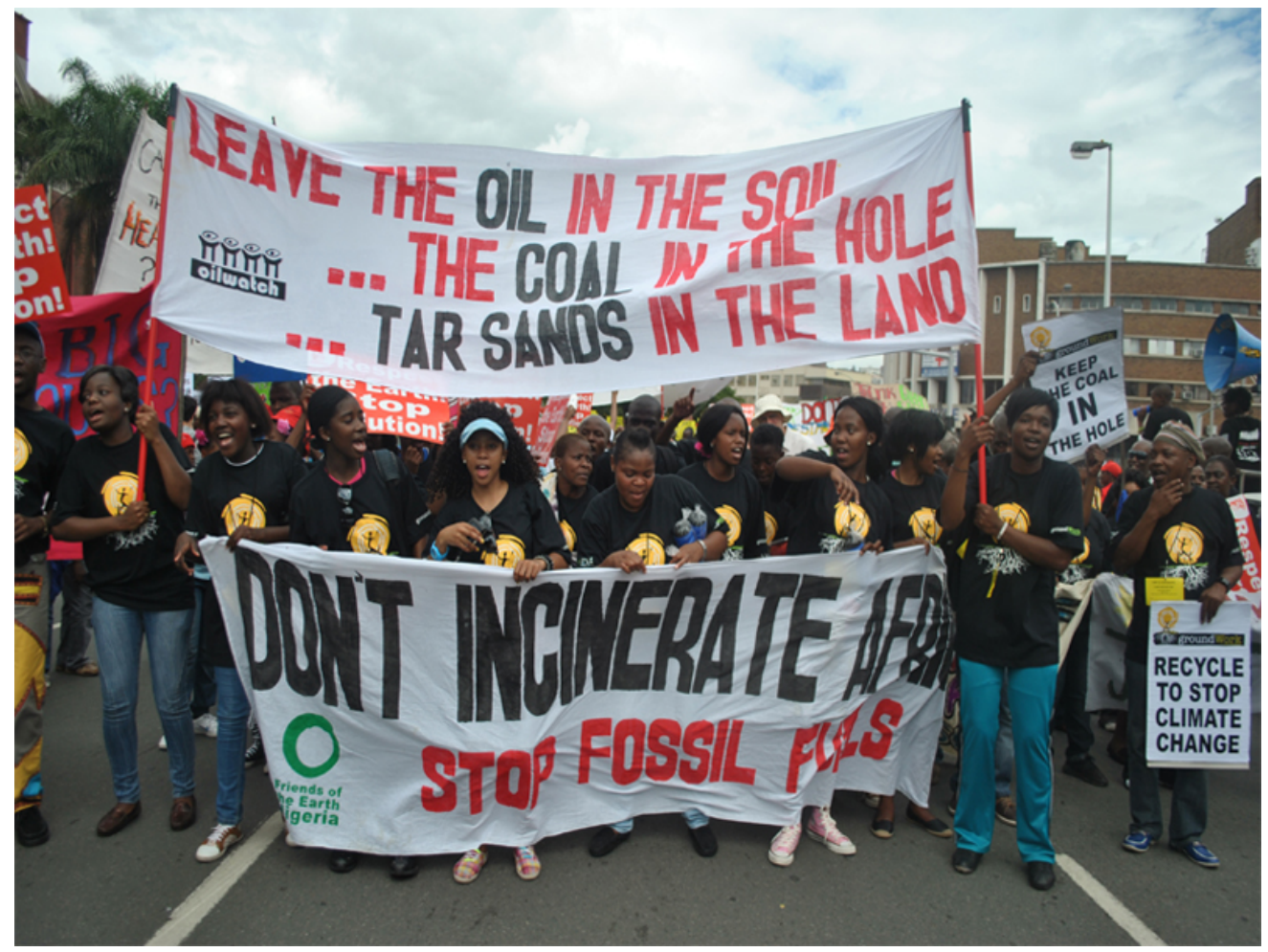

Figure 10: Leave oil in the soil: demonstrators in the COP17 demand leaving fossil fuels in the ground, Durban, December 6, 2011. Source: Friends of the Earth Nigeria / Oilwatch.

In the Niger Delta, the demand has been for "self-determination" and "resource control", and for reparations for damages. The non-violent MOSOP (Movement for the Survival of the Ogoni People) made worldwide news in 1995 with the killing of its leader Ken Saro-Wiwa and comrades by the military dictatorship. Before this, there were many other acts of resistance.

On 4 January 1993, as the United Nations marked World Indigenous Populations day, an estimated 300,000 Ogoni, including women and children staged a historic non-violent protest, and marched against Shell's "ecological wars". With the expiration of the notice to quit, Shell was expelled from Ogoni. Eventually, failure to adhere to the warnings and frequent government reprisal attacks and human rights violations resulted in the death of hundreds of Ogonis, following which Shell had no option but to end its oil extraction in Ogoni. This event represents on a global scale, the most formidable community wide resistance to corporate oil operations, paving the way to keeping oil underground in Ogoni (Ojo 2013).

So, while the term "to Yasunize" gained international currency to describe social demands for the protection of territories of special interest due to their natural and cultural diversity or riches, it was in Ogoni where we find the first known example of leaving oil underground. Thus, the question remains whether it is "Yasuni that is being Ogonised or Ogoni that is being Yasunised?" (Ojo 2013). 


\section{Corporate accountability and criminalization of activists}

EJ activists consider Corporate Social Responsibility (as opposed to Corporate Accountability) as pure greenwashing. It seems that the environmental activist Jay Westerveld coined the term greenwashing in the late 1980s, to criticize hotels presenting themselves as environmentally friendly by inviting guests to reuse towels as a contribution to save the environment (Motavalli 2011). EJOs adopted the concept and extended its application to refer to all industry strategies and practices that market their environmentally and socially destructive activities as sustainable (e.g. GRAIN 2006 and WRM 2010). One celebrated case is that of Stephan Schmidheiny, described in the EJOLT blog as the king of greenwashing, and founder of the Business Council for Sustainable Development in 1991. He was sentenced to 16 years imprisonment on 13 February 2012 by an Italian court (later increased to 18 years), for criminal negligent behavior in exposing many of Eternit's workers and citizens to asbestos in the 1970s. The sentence has been appealed twice as of early 2014.

Corporate fantasies such as the "triple bottom line", "sustainable mining" or even some timber certification schemes are described as "greenwashing" by EJOs. This is illustrated by the 'International Declaration Against the 'Greenwashing' of Palm Oil', by the Roundtable on Sustainable Palm Oil, signed by over 250 organisations worldwide. ${ }^{53}$ In a similar ironic vein, consider toxic tours. While "eco-efficiency" environmentalists enjoy showing "best technical practices" including "sustainable tourism", the EJ activists scoff at such words and they have organized toxic tours showing pollution horrors to their guests - even though they themselves are not against good technical practices including novelties in water harvesting or in solar energy.

In the period between 1992 and 2002 (Broad 2002; Broad and Cavanagh 1999) the EJOs developed the concept of corporate accountability that Friends of the Earth International (whose president was then Ricardo Navarro, from the EJO Cesta in El Salvador) defended vigorously at the 2002 Johannesburg UN summit (WSSD) proposing the adoption of a Corporate Accountability Convention (Utting 2008). Greenpeace also proposed the adoption of the Bhopal Principles on Corporate Accountability and Liability.

In the movement for corporate accountability and liability, the EJOs have been active in bringing corporations to court. In the case of United States corporations causing damages abroad, appeal has been made to the ATCA (Alien Torts Claim Act) (Utting 2008: 108 provides a list of cases). For other countries, lawyers have sought other laws. The Chevron Texaco case against their impacts in the Ecuadorian Amazon was initially taken to the United States in 1993 under ATCA. It then went back to Ecuador whose courts decided in favour of the plaintiffs in 2011, 2012 and 2013, with much support from civil society. Arguably, the Frente de Defensa de la Amazonia (formed by indigenous and settler representatives) should be seen as an EJO as two of its leaders, Luis Yanza and lawyer Pablo Fajardo were awarded the Goldman Prize in 2008 for this community-driven legal battle. At present the lawyers of the Frente de Defensa de la Amazonia are trying to collect damages from Chevron in several countries.

This, and similar cases, are examples of what Boaventura de Souza Santos (a scholar who works with activists) calls subaltern legality, i.e. the efforts of communities whose livelihoods and identity are negatively affected by corporations or states to use the existing legal apparatus to seek redress for injustice, and to claim accountability and therefore compensations or reparations (Santos and Rodríguez-Garavito 2005; Utting 2008). EJOLT has published detailed reports (by Antoni Pigrau et al. 2012, 2013) on the legal avenues available to EJOs to exercise such subaltern legality and claim environmental liabilities or ecological debts. The ATCA avenue seems to be closing after the 2013 Kiobel vs. Shell Supreme Court decision in the USA. Kiobel is the name of one of the companions of Ken Saro-Wiwa (killed in 1995). One could conclude that there is no way of obtaining environmental justice in rich countries' courts for damage done in the South.

EJOs have placed emphasis on the notion of liability, and also on the right to know the operations of transnational corporations. It is very difficult for consumers to know the origins of some commodities, or the destination of profits. One could perhaps trace the geographical and social origins of precious timber, coffee, gold or diamonds (as in the Kimberley process against trade in blood diamonds, now in deep trouble) but it is

\footnotetext{
${ }^{53}$ Overbeek et al. 2012. Also http://www.ejolt.org/2013/11/calabar-declaration
} 
well nigh impossible for a consumer to know where bulk commodities such as oil, coal or copper come from. Consumers in importing countries suffer irremediably from consumer blindness (Healy et al. 2013).

Beyond the movement for corporate accountability and liability, the use of another new concept is growing in the global EJ movement, that of ecocide. It first use apparently goes back to the Vietnam War, when American scientists concerned about the use of Agent Orange started a movement to ban what they called "ecocide", the destruction of a natural environment to the extent that its human inhabitants were endangered (Zierler 2011). The term was re-introduced by London barrister and legal scholar Polly Higgins. In March 2010 she proposed to the UN that ecocide be a new type of crime against peace. In Germany, Ökozid was a book series and a journal running 1985 to 2000. There is a global mapping on ecocide underway (http://wish20.upriser.com) and there is a civil society initiative ("End Ecocide") to collect one million citizens' signatures to be delivered to the European parliament to try and make ecocide a crime. There are many calls from EJOs for an international environmental crimes tribunal. ${ }^{54}$

"Ecocide" is complementary to demands for civil liabilities. On $19^{\text {th }}$ March 2013, Nnimmo Bassey (former president of Friends of the Earth International, executive secretary of Oilwatch) marked the first 20 years of activity by ERA and the partially successful attempts to bring Shell to court in The Netherlands for its socio-environmental liabilities in the Niger Delta. Speaking in Abuja he recalled that:

...(although) we sometimes resort to civil (legal) actions as a measure of resistance we note that these are not sufficient to stem environmental crimes. To stop those who reap profits from environmental damage, laws governing those activities ought to be urgently upgraded to make it possible for criminal charges with long jail terms to be pressed against individual criminals and those who hide behind corporate shields. Ecocide would be an appropriate umbrella law to confront the massive lawlessness that runs rampant across Nigeria and many nations of the world today. ${ }^{55}$

Instead of criminalizing the companies or state actors destroying natural environments and human livelihoods, the EJOs worldwide know that it is the environmental defenders who are often repressed, 'criminalized' by the state and killed by the police, hired gunmen or paramilitary forces. Many well known "environmentalists of the poor" have been killed since Chico Mendes in 1988 and Ken Saro-Wiwa and companions in 1995. In 2012 the NGO Global Witness produced a report on hundreds of environmentalists murdered, including fisherfolk, indigenous people and peasants who defended their territories where nature, life and culture are strongly connected (Global Witness 2012).

Of the three streams of environmentalism in the world today (Conservationism/EcoEfficiency/Environmental Justice), the third one is by far the one that contributes the largest number of victims. In their claims, activists denounce the violation of human rights and also of the Rights of Nature (as included in Ecuador's Constitution of 2008, article 71, after an original idea from Acción Ecológica). EJOs see themselves as fighting crimes against humanity and crimes against nature. They want go beyond "anthropocentrism" into the defence of Mother Nature by a variety of means.

\section{Discussion}

The present article attempts to do three things. First, it reinforces the thesis that there is a global environmental justice movement (Sikor and Newell 2014). Second, it traces the origins and explains much of the vocabulary of this global EJ movement that was born and has grown since the 1980s and 1990s. Third, it emphasizes the fact that many (but not all) the concepts and slogans of the EJ movement were born outside academia, as indeed also happened with other social movements where crucial concepts (the right to one's own body in Feminism, or the slogan land to the tiller in agrarian movements) emerged in the homes, in the streets or in the fields. Academic research supports the movements by refining such concepts and sometimes

\footnotetext{
${ }^{54}$ See the interviews with general attorney Antonio Gustavo Gómez of Tucuman, Argentina in the EJOLT documentary on dimensions of environmental justice; http://www.youtube.com/watch?v=JSPBRG3GZDo

${ }^{55}$ http://www.ejolt.org/2013/03/era-twenty-years-of-fighting-environmental-crimes
} 
providing new ones. Several of the EJ activists' concepts and proposals listed here as a "political ecology from the bottom up", have later given birth to research programs in the social sustainability sciences.

The EJ movement started to grow in the 1980s and 1990s out of many conflicts over resource extraction and waste disposal, due to the increase in social metabolism. Riding on this movement, a statistical political ecology is being developed in the 2010s with inventories and maps of environmental conflicts worldwide, often done by EJOs or networks of EJOS or at other times based on collaboration between academics and EJOs, as in the EJOLT project.

Sometimes a doubt is voiced that belief in environmental constraints or planetary boundaries entails a threat to liberal democracy, and to individual rights. An international eco-bureaucracy (already described as the "IMF of Ecology" in Martinez-Alier 1991) would impose top-down limits to economic and population growth, drawing up eco-adjustment plans for all countries of the South. Alternatively, environmental threats would entail a retreat into particularistic bio-regionalisms and "life-boat ethics" excluding strangers and foreigners by force if needed. Such anti-democratic trends certainly exist. However, there is also an opposite trend of "social-environmental cosmopolitanism", embodied in the global environmental justice movement. "Cosmopolitanism" means the notion that people are bound together by their common humanity, and indeed by their common belonging to and reliance on nature. This implies duties of care towards fellow humans and towards nature that cannot be sacrificed to identification with family, ethnic group, religion or social class (Dobson 2012: 247).

The United States environmental justice movement of the early 1980s started off with complaints against environmental racism but it soon became concerned with environmental justice worldwide. The meetings at the World Social Forums with thousands of activists, the world assemblies of La Via Campesina (with over one thousand participants from many countries), the smaller meetings of Friends of the Earth International and other networks, are the main occasions where the environmental justice activists strategize, supplementing their contacts through internet. This is socio-environmental cosmopolitanism at its best, where concepts such as ecological debt, climate justice, biopiracy, food sovereignty and many other have been nurtured. At the 2004 WSF in Mumbai, many activists from other countries heard directly from Dalits and Adivasis for the first time in their lives. This was not an addition of new particularisms, but on the contrary it was an expansion of the scope of socio-environmental justice to realities not always understood outside India. It was not difficult for many participants from Latin America and Africa to identify with Dalits and Adivasis.

The World Social Forums of the 2000s certainly pushed forward the globalization of EJ. The alternative "treaties" signed at Rio de Janeiro in 1992 had already shown the many links existing among environmental groups. Friends of the Earth (born in California) became international, bringing in organizations already active since the 1980s like CENSAT in Colombia or WAHLI in Indonesia. But, outside Friends of the Earth, one could also find other important local organizations linking the environmentalism of the poor with wider notions of environmental justice and climate justice, as the Centre for Science and Environment did in Delhi in 1991. A global EJ movement was in full swing in the 1990s, and aware of itself. In the best research on this movement, this awareness is recognized (Sikor and Newell 2014). Activistacademics belonging to the United States EJ movement travelled and became influential in South Africa and Brazil since the early 1980s, also contributing to the creation of EJ networks (Porto 2012b). At least since the mid-1990s academic work has made explicit the connections between the EJ movement in the United States and other manifestations of EJ in Latin America, Africa and Asia (Martinez-Alier 1997; Featherstone 2013; Guha and Martinez-Alier 1997, 1999). These connections had become obvious after the deaths of Chico Mendes in 1988 and Ken Saro-Wiwa and his Ogoni comrades in 1995. By the mid-1990s classic books written by activists analyzing EJ movements across the world had been published; against dams (McCully 1996) and against tree plantations (Carrere and Lohman 1996).

In academia, the last decades have seen the growth of the social sustainability sciences, such as human ecology, ecological economics, political ecology, environmental law, human geography, environmental sociology, ecological anthropology, environmental history, environmental politics, urban ecology, agroecology, industrial ecology, environmental toxicology and public health. The very names of such fields or disciplines are of academic origin, with journals, doctoral programmes, research institutes and some named professorships. Environmental activists profit critically from them; close working connections are due in part to the fact that in some European countries some activists-turned-professors research and teach in 
institutes initiated by civil society that have become a recognized component of the academic system. They range from Wetenschapswinkeln in the Netherlands, to green research institutions like the New Economics Foundation or IIED in the UK, and the Ökoinstitut in Germany.

In this article we have not focused on "capacity building" for civil society organizations. On the contrary, we examined activist-led science, i.e. civil society's ability to conduct research and create concepts of political ecology "from the ground up." These are then taken up, with or without acknowledgement, refined, and applied by academics and so-called policy makers. We have analyzed such concepts, explaining the context in which they have emerged over the last thirty years: environmental justice, popular epidemiology, environmental racism, sacrifice zones, the environmentalism of the poor, ecological debt, biopiracy, climate justice, water or hydric justice, food sovereignty, "tree plantation are not forests", green deserts, land-grabbing, Yasunization and Ogonization, "leave oil in the soil, leave coal in the hole", resource caps, transit justice, urban waste recyclers, zero waste, "peasant agriculture cools down the Earth", corporate accountability and liability, local referendums with veto power, unmasking of greenwashing, consumer blindness, the alliance between the degrowth movement and environmental justice, a different financial system not based on increasing public or private debts, support for the concept of ecocide and the proposal for an international court for environmental crimes, stopping the so-called "criminalization" of activists by states, enforcement of indigenous territorial rights, the rights of nature, and the post-extractivist economy, and more.

One could ask why the term environmental justice has entered general use to a much greater extent than the other terms considered in this article. One reason is that EJ is more encompassing in its reach than climate justice or water justice. Another complementary, tentative explanation is that EJ was in circulation earlier than other terms, and by the early 1980s in the United States. Other concepts, such as the environmentalism of the poor, the ecological debt, and biopiracy date from the late 1980s or early 1990s. However, the defense of indigenous territorial rights and the defence of the commons, and perhaps working class environmentalism and ecofeminism, which are terms used nowadays in the global environmental justice movement, date from the 1970s or even much before this.

Unlike academics, activists do not usually claim authorship rights to such concepts. Activists do not care about impact factors in refereed academic journals but they do care about the social success of their proposals. The activists' neglect of academic values favors cooperation between activist and academics because they do not compete for the same turf. However, tension arises if and when activists suddenly perceive that their ideas are being pinched by academics for professional advantage.

There are people in the social sustainability sciences (also in feminist scholarship and other fields) who simultaneously belong to the worlds of activism and academia. A few activist-authors (such as Bob Bullard in the US since the 1980s, and Patrick Bond in South Africa) appear by name in our account. They should not be seen as "organic intellectuals" (in Gramsci's sense), leaders of movements from behind the scene, but rather (together with non-activist authors) as useful intellectual scavengers who take up concepts conceived in strategy meetings or in the heat of battle by EJOs, and then define, refined, dissect and classify, allowing transfer and application to other geographical contexts.

Ecological distribution conflicts over resource extraction, transportation and infrastructure, and waste disposal arise because of the growth of social metabolism and because of the structural asymmetries in the burdens of pollution and in the access to natural resources that are grounded in unequal distributions of power and income, in social inequalities of ethnicity, caste, social class and gender. For instance, many populations who will suffer most from climate change (and are supposed to start "adapting" to it) are historically or currently not responsible for it, because their emissions are below two tonnes of carbon dioxide per person per year. Hence the claims for a climate debt as part of a larger ecological debt that also includes a debt for ecologically unequal trade, and a debt for biopiracy.

Instead of further accumulation of profits and capital by dispossession and contamination, EJOs propose that the economic system should change to a steady state economy after a period of degrowth in the rich countries, an economy characterized by "prosperity without growth" with a much greater degree of social equality, at least halving the current rate of extraction of fossil fuel to prevent climate change and avoid damage to nature and to human rights at the frontiers of extraction and land grabbing. This should go 
together with resource caps on extraction of materials, for instance export quotas on minerals and biomass. These are demands from local EJOs.

The flows of energy and materials in the world economy have never been so large. This increased social metabolism is causing more and more ecological distribution conflicts. This has given rise to a social movement for EJ around the world formed by many organizations and networks which put forward their own concepts and proposals for action, and criticize and even denounce other concepts as "greenwashing."

Practice draws on theory, but practice also produces theory. EJOs often draw upon concepts coming from the sustainability sciences, for instance they know, use and sometimes criticize the ecological footprint, the HANPP (human appropriation of net primacy production of biomass), "peak oil" and the EROI, material flow analysis, the Environmental Kuznets Curve, life-cycle analysis, ecological terms of trade, cost-benefit analysis and multi-criteria assessment, resilience, valuation of ecosystem services... EJOs tend to use the notion of ecological footprint, which is the inverse of "carrying capacity", i.e. not the maximum number of people (or any other species) that a given territory may hold but the actual space directly and indirectly used by a given number of people. The EJOs have conceptual and moral difficulties in dealing with population issues and Malthusianism, but perhaps they are moving slowly to support bottom-up feminist neoMalthusianism as proposed by Emma Goldman and Maria Lacerda de Moura one hundred years ago.

EJOs also create new concepts. In EJOLT (as in a previous project, CEECEC, Martinez-Alier et al. 2011; Healy et al. 2012) we navigate between science and activism in the fields of ecological economics and political ecology.

\section{Conclusion}

To conclude, the world of EJOs has come to exist because of the many conflicts caused by the increase of social metabolism and global inequalities of power and income. These have resulted in injustices in access to natural resources and in the burdens of pollution. EJOs were not born from reading books but have produced their own books (and documentaries) as byproducts of their activism. The EJ movements respond to and express the conflicts that arise from the clash between economic growth and the environment as a source of livelihoods and as a site of cultural values. They are certainly not a "post-materialist" movement in Ronald Inglehart's sense. Political scientists and social historians might be interested in environmental justice as one more "social movement" with its repertoire of actions. This is certainly an interesting approach. However, for practitioners, more interesting are the possible alliances with other social movements in a "global justice movement of movements", and this might have had its première in Seattle in 1999. The main reasons for action are very practical environmental reasons reinforced by the linkages between local and global issues and networks. This was so from the beginning in the United States where Civil Rights, plus the fight against waste dumping produced the Environmental Justice Movement (Figure 1), to today in the Amazon of Ecuador against new oil and mining projects, or in the Niger Delta against gas flaring and oil spills.

EJOs and their networks are developing a "political ecology from the bottom up", overlapping with the academic social sustainability sciences. They are interesting to analysts of new social movements but they are even more interesting for their efforts to change the economic, political and cultural systems in the direction of sustainability. There were many environmental struggles before the term environmental justice was introduced by activists (Armiero 2008). This is common. There were strikes before the word "strike" was first used internationally, in different languages, as a collectively organized cessation of work, and there were collective demands for improved working conditions before the "labour movement" or "working class" movement became aware of itself.

The main concepts used by the global environmental justice movement since the 1980s, including that of environmental justice itself, do not come from academic research but from the strategies and battles of the movements themselves. Such concepts are not initially validated by publication in peer-reviewed journals. They are used politically whether academic recognition is or is not achieved, and may then permeate into the academic agenda. The test of their validity is acceptance within the movement itself in concrete battles, in international meetings and by sympathetic observers from academia or governments or the UN bureaucracy. Thus, the grassroots movement against privatization of urban water services rightly glorifies the struggle in 
Cochabamba, Bolivia in 2000 led by activist Oscar Olivera. Years later, with Pablo Solon as Ambassador to the UN, the government of Bolivia pushed the UN to declare access to water as a human right. The EJOs' concepts are meant to influence political reality and they are sometimes translated into practical politics and public policies. As with ecological debt, there are long incubation periods between the time when a new concept is introduced at the cutting edge of the global environmental justice movement and the time when the same concept becomes an object of mainstream academic research and publication or is applied, or at least mentioned, in governmental policy documents or decisions.

\section{References}

Acosta, A. and Martínez, E. 2009. El buen vivir. Una vía para el desarrollo. Quito: Abya-Yala.

Acosta, A. 2013. El Buen Vivir. Sumak Kawsay, una oportunidad para imaginar otros mundos. Barcelona: Icaria.

Action Aid 2009. Rich countries "climate debt" and how they can repay it: an Action Aid rough guide. Johannesburg: Action Aid International. Online: http://climatedebt.org/wpcontent/uploads/2009/11/climate-debt-briefing-october-2009.pdf

Agarwal, A. and S. Narain. 1991. Global warming in an unequal world: a case of environmental colonialism. New Delhi: Centre for Science and Environment.

Agarwal, B. 1992. The gender and environment debate: lessons from India. Feminist Studies 18(1): 119-158.

Agarwal, B. 2001. Participation exclusion, community forestry, and gender: an analysis for South Asia and a conceptual framework. World Development 29(10): 1623-1648.

Agyeman J. and T. Evans. 2003. Toward just sustainability in urban communities: building equity rights with sustainable solutions. Annals of the American Academy of Political and Social Science 590: 35-53.

Agyeman J, Bullard R.D. and B. Evans (eds.) 2003. Just sustainabilities: development in an unequal world. Cambridge: The MIT Press.

Alkon A.H. and J. Agyeman. 2011. Cultivating food justice: race, class, and sustainability. Cambridge: The MIT Press.

Altvater, E. 1993. The future of the market: an essay on the regulation of money and nature after the collapse of 'actually existing socialism'. London: Verso.

Anguelovski, I. 2014. Neighborhood as refuge: environmental justice, community reconstruction, and placeremaking in the city Cambridge, Mass.: MIT Press.

Arana, M. 2013. De izquierdas, derechas y ecologismo libertario. El Comercio (Lima) 27 March.

Armiero, M. 2008. Seeing like a protester: nature, power, and environmental struggles. Left History 1: 59-76.

Armiero, M. and D'Alisa, G. 2012. Rights of resistance: the garbage struggles for environmental justice in Campania, Italy. Capitalism, Nature, Socialism 23(4): 52-68.

Asara, V., Profumi, E. and G. Kallis. 2013. Degrowth, democracy and autonomy. Environmental Values 22(2): 217-239.

Barca, S. 2012. On working-class environmentalism: an historical and transnational overview. Interface: a journal for and about social movements 2:61-80.

Barkan, E. 2000. The guilt of nations: restitution and negotiating historical injustices. New York: Norton.

Batterbury, S.P.J. 1996. Ted Trainer and the conserver society. West London Papers in Environmental Studies 3: 1-12.

Bayon, D., F. Flipo, F. Schneider 2010. La décroissance, 10 questions pour comprendre et en débattre. Paris: La Découverte.

Bhagwati, J. 2010. A new approach to tackling climate change. Financial Times 22 Feb 2010. http://www.ft.com/intl/cms/s/0/c9ee09b0-1fe7-11df-8deb-00144feab49a.html\#axzz2qbPnRKCX

Boelens, R., Cremers, L. and Zwarteveen, M. (eds.) 2011. Justicia hídrica. acumulación, conflicto y acción social. Lima: Instituto de Estudios Peruanos.

Boix, V. 2007. El parque de las hamacas, Barcelona: Icaria. 
Bonaiuti, M. 2011. From bioeconomics to degrowth. London: Routledge.

Boardman, B. 2009. Fixing fuel poverty: challenges and solutions. London: Routledge.

Bond, P. 2010. Repaying Africa for climate crisis: 'Ecological debt' as a development finance alternative to emissions trading. In Böhm, S. and S. Dabhi (eds.) Upsetting the offset: the political economy of carbon trading. London: MayFlyBooks.

Bond, P. 2014. Climate justice. In C. Death (ed.) Critical environmental politics. London: Routledge.

Bond, P. Sharife, K., Allen F., Amisi B., Brunner K, Castel-Branco, R., Dorsey D., Gambirazzio, G., Hathaway, T.,Nel, A. and W. Nham. 2012. The CDM cannot deliver the money to Africa. Why the Clean Development Mechanism won't save the planet from climate change, and how African civil society is resisting, EJOLT Report 2, $120 \mathrm{p}$.

Borrero, J.M., 1994. La deuda ecológica. Testimonio de una reflexión. Cali: FIPMA.

Botzen, W.J.W., J.M. Gowdy and J.C.J.M. van den Bergh 2008. Cumulative $\mathrm{CO}_{2}$ emissions: shifting international responsibilities for climate debt. Climate Policy 8: 569-576.

Broad, R. and J. Cavanagh. 1999. The corporate accountability movement: lessons and opportunities. The Fletcher Forum of World Affairs 23(2): 151-169.

Broad, R. (ed.) 2002. Global backlash: citizen initiatives for a just world economy. New York: Rowman and Littlefield.

Brown, P. 1992. Popular epidemiology and toxic waste contamination: lay and professional ways of knowing. Journal of Health and Social Behavior 33: 267-281.

Brown, P. 1997. Popular epidemiology revisited. Current Sociology 45: 137-156.

Bruno, K., Karliner J. and C. Brotsky. 1999. Greenhouse Gangsters vs. Climate Justice. San Francisco: CorpWatch.

Bryant B.I. and P. Mohai. 1992. Race and the incidence of environmental hazards: a time for discourse. Boulder: Westview Press.

Bullard R.D. 1990. Dumping in Dixie: race, class, and environmental quality. Boulder: Westview Press.

Bunker, S. 1985. Underdeveloping the Amazon.: extraction, unequal exchange, and the failure of the modern state. Chicago: University of Chicago Press.

Burke, B.J. 2012. Transforming power in Amazonian extractivism: historical exploitation, contemporary fair trade and new possibilities for indigenous cooperatives and conservation. Journal of Political Ecology 19: $113-125$.

Carlsson, C. 2008. Nowtopia: how pirate programmers, outlaw bicyclists and vacant-lot gardeners are inventing the future today. Oakland, CA: AK Press.

Carlsson, C., Elliott, L.R. and Camarena, A. 2012. Shift happens: Critical Mass at 20. San Francisco: Full Enjoyment Books.

Carney, M.A. 2014. The biopolitics of 'food insecurity': towards a critical political ecology of the body in studies of women's transnational migration. Journal of Political Ecology 21: 1-18.

Carrere, R. and L. Lohman. 1996. Pulping the South: industrial tree plantations and the world paper economy. London: Zed Books.

Casarino, C. and A. Negri. 2008. In praise of the common: a conversation on philosophy and politics. Minneapolis: University of Minnesota Press.

Cattaneo, C. 2006. Investigating neorurals and squatters' lifestyles: personal and epistemological insights on participant observation and on the logic of ethnographic investigation. Athenea Digital 10: 16-40.

Cattaneo, C. 2011. The money-free life of Spanish squatters. In A. Nelson (ed.) Life without money. London: Pluto Press.

Cattaneo, C., D'Alisa, G., Kallis, G. and C. Zografos. 2012. Degrowth futures and democracy. Futures 44 (6): 515-523.

Chatterton, P. and J. Pickerill. 2010. Everyday activism and transitions towards post-capitalist worlds. Transactions of the Institute of British Geographers 35: 475-490. 
Christian Aid. 2009. Climate debt and the call for justice: signposts to Copenhagen 5. London: Christian Aid. Online: http://www.christianaid.org.uk/images/signposts-climatedebt.pdf

Conill, J., Castells, M., Cardenas, A. and L. Servon. 2012. Beyond the crisis: the emergence of alternative economic practices. In M. Castells, J. Caraça, and G. Cardoso (eds.) Aftermath: the cultures of the economic crisis. Oxford: Oxford University Press.

Connolly, J. and J. Steil. 2009. Can the Just City be built from below? Brownfields, planning, and power in the South Bronx. In Marcuse P. (ed.) Searching for the just city : debates in urban theory and practice. London, New York: Routledge. Pp. 173-193.

Corburn, J. 2005. Street science: community knowledge and environmental health justice. Cambridge: MIT Press.

Corburn, J. 2009. Toward the healthy city: people, places, and the politics of urban planning. Cambridge: MIT Press.

de Angelis, M. 2007. The beginning of history: value struggles and global capital. London: Pluto Press.

D'Eaubonne, F. 1974. Le feminisme ou la mort. Paris: Pierre Horay Ed.

Demaria, F. 2010. Shipbreaking at Alang-Sosiya (India): an ecological distribution conflict. Ecological Economics 70: 250-260.

Demaria, F., Tasheva, E. and I. Hlebarov. 2012. Industrial (toxic) waste conflicts around the world. Case studies from India and Bulgaria: shipbreaking and incineration. EJOLT report No. 1, 68 p.

Demaria, F., Schneider, F., Sekulova, F. and J. Martinez-Alier. 2013. What is Degrowth? From an activist slogan to a social movement. Environmental Values 22(2): 191-215.

Di Chiro, G. 1998. Nature as community: the convergence of social and environmental justice. In M. Goldman (ed.) Privatizing nature: political struggles for the global commons. London: Pluto.

Dobson, A. 2013. Political theory in a closed world: reflections on William Ophuls, liberalism and abundance. Environmental Values 22(2): 241-259.

Downey L and Hawkins B. 2008. Race, income, and environmental inequality in the United States. Sociological Perspectives 51: 759-781.

Duverger, T. 2011. La décroissance, une idée pour demain: une alternative au capitalisme. Paris: Sang de la Terre.

Economist. 2013. Unburnable fuel. The Economist 4 May 2013.

Elzen, M.G. den and M. Schaeffer. 2002. Responsibility for past and future global warming: uncertainties in attributing anthropogenic climate change. Climatic Change 54: 29-73.

Emanuelli, M.S., Jonsén, J. and Monsalve Suárez, S. 2009. Red sugar, green deserts. FIAN International, FIAN Sweden, HIC-AL, and SAL. http://www.fao.org/docs/eims/upload/276609/monocultures.pdf (accessed April 2nd, 2013).

Enting, I.G. and R.M. Law. 2002. Characterising historical responsibility for the greenhouse effect. CSIRO Atmospheric Research Technical Paper no. 41. Aspendale, Australia: CSIRO.

Escobar, A. 1998. Whose knowledge, whose nature? Biodiversity, conservation, and the political ecology of social movements. Journal of Political Ecology 5: 53-82.

Escobar, A. 2008. Territories of difference: place, movements, life, redes. Durham NC: Duke University Press.

FASE and TNI. 2003. Where the trees are a desert: stories from the ground. Vitoria: Federation of Organizations for Social and Educational Assistance and Amsterdam: Transnational Institute.

Featherstone, D. 2013. The contested politics of climate change and the crisis of neo-liberalism. ACME: An International E-Journal for Critical Geographies 12(1): 44-64.

Fischer-Kowalski, M. and H. Haberl. 1997. Tons, joules and money: modes of production and their sustainability problems. Society and Natural Resources 10(1): 61-85.

Fitzgerald J. 2010. Emerald cities: urban sustainability and economic development. New York: Oxford University Press.

Flipo, F. 2007. Voyage dans la galaxie décroissante. Mouvements 50 (2): 143-151. 
Friends of the Earth International [FOEI] 2005. Climate debt: making historical responsibility part of the solution. $\quad$ http://www.foei.org/en/resources/publications/climate-justiceand-energy/20002007/climatedebt.pdf/at_download/file

Friman, M. 2013. Historical responsibility: assessing the past in international climate negotiations. PhD dissertation. Linköping: Linköping Studies in Arts and Science.

Funtowicz S., Ravetz J.R. 1993. Science for the post-normal age. Futures 25:735-755.

Gadgil, M. and V.D.Vartak. 1976. Sacred groves of Western Ghats of India. Economic Botany 30:152-160.

Gadgil, M., Berkes, F. and C. Folke. 1993. Indigenous knowledge for biodiversity conservation. Ambio 22(23).

Georgescu-Roegen N. 1971. The entropy law and the economic process. Cambridge: Harvard University Press.

Georgescu-Roegen N. 1979. Demain la décroissance : entropie-écologie-économie. Preface and translation by Ivo Rens and Jacques Grinevald. Lausanne: Pierre-Marcel Favre.

Global Witness. 2012. A hidden crisis? Increase in killings as tensions rise over land and forests. London/Washington DC: Global Witness.

Godard, O. 2012. Ecological debt and historical responsibility revisited - the case of climate change. EUI Working Papers. RSCAS 2012/46. Robert Schuman Centre for Advanced Studies. Global Governance Programme-26. Florence: European University Institute. http://cadmus.eui.eu/handle/1814/23430

Gorz, A. 1982 (1980). Farewell to the working class: an essay on post-industrial socialism. London: Pluto Press.

Gottlieb R. 2005. Forcing the spring: the transformation of the American environmental movement. Washington, DC: Island Press.

Gottlieb R. 2009. Where we live, work, play . . . and eat: expanding the environmental justice agenda. Environmental Justice 2: 7-8.

Gottlieb R. and Joshi A. 2010. Food justice. Cambridge: MIT Press.

GRAIN 2005. Food sovereignty: turning the global food system upside down. Seedling. http://www.grain.org/article/entries/491-food-sovereignty-turning-the-global-food-system-upsidedown (accessed March 28th, 2013).

GRAIN 2006. Sustainable monoculture? No thanks! http://www.grain.org/article/entries/157-sustainablemonocultures-no-thanks (accessed April 2nd, 2013).

Greyl, L.,Vegni, S., Natalicchio, M., Cure, S. and J. Ferrett. 2012. The waste crisis in Campania. In Healy, H., J. Martinez-Alier, L. Temper, M. Walter, and J.F. Gerber (eds.) 2012. Ecological economics from the ground up. London: Routledge.

Gudynas, E. 2008. Más que Deuda, un Robo. http://www.deudaecologica.org/Que-es-DeudaEcologica/MAS-QUE-DEUDA-UNROBO.html

Gudynas, E. 2011. Desarrollo, postextractivismo y "buen vivir". Revista Pueblos 49.

Gudynas, E. 2012. Estado compensador y nuevos extractivismos. Las ambivalencias del progresismo sudamericano. Nueva Sociedad 237:128-146.

Guha, R. and J. Martinez-Alier. 1997. Varieties of environmentalism: essays North and South. London: Earthscan.

Guha, R. and J. Martinez-Alier. 1999. Political ecology, the environmentalism of the poor and the global movement for environmental justice. Kurswechsel 3: 27-40.

Guy C, Graham C. and E. Heather. 2004. Food retail change and the growth of food deserts: a case study of Cardiff. International Journal of Retail and Distribution Management 32: 72-88.

Haas W., Heinz, M., Krausmann, F. and D. Wiedenhofer. (forthcoming). The current state of the global economy's circularity: a socio-metabolic analysis. In: Fischer-Kowalski, M., Haberl, H., Krausmann, F. and V. Winiwarter. (eds.) Society-nature interaction and its history. Netherlands: Springer.

Hardin, G. 1968. The tragedy of the commons. Science 162: 1243-1248.

Harrison J.L. 2011. Pesticide drift and the pursuit of environmental justice. Cambridge: The MIT Press. 
Hardt M. and A. Negri. 2009. Commonwealth. Cambridge: The Belknap Press of Harvard University Press. Harvey, D. 2004. The 'new' imperialism: accumulation by dispossession. Socialist Register 40: 63-87.

Healy, H., J. Martinez-Alier, L. Temper, M. Walter, and J.F. Gerber (eds.) 2012. Ecological economics from the ground up. London: Routledge.

Hess D.J. 2009. Localist movements in a global economy: sustainability, justice, and urban development in the United States. Cambridge: The MIT Press.

Hornborg, A. 1998. Towards an ecological theory of unequal exchange. articulating world system theory and ecological economics. Ecological Economics 25: 127-136.

Hornborg, A. 2005. Footprints in the cotton fields: the Industrial Revolution as time-space appropriation and environmental load displacement. Ecological Economics 59: 74-81.

Hornborg, A. 2009. Zero-sum world. International Journal of Comparative Sociology 50 (3-4): 237-262.

Hornborg, A. 2011. Global ecology and unequal exchange: fetishism in a zero-sum world. London: Routledge.

Hornborg, A., McNeill, J.R. and J. Martinez-Alier (eds.) 2007. Rethinking environmental history, worldsystem history and global environmental change. Lanham, MD: Atamira Press.

Isch, E., Boelens, R., and F. Peña (eds.). 2012. Agua, injusticia y conflictos. Lima: Instituto de Estudios Peruanos.

Jackson, T. 2011. Prosperity without growth: economics for a finite planet. London: Earthscan.

Jenkins, T.N. 1996. Democratising the global economy by ecologicalising economics: the example of global warming. Ecological Economics 16: 227-238.

Jernelöv, A. 1992. Miljöskulden. En rapport om hur miljöskulden utvecklas om vi ingentinggör. SOU 1992: 58. Stockholm: Allmänna förlaget.

Jubilee Debt Campaign. 2007. Debt and climate change. Briefing 07. London: Jubilee Debt Campaign.

Kallis, G., Kerschner. C. and J. Martinez-Alier. 2012. The economics of degrowth. Ecological Economics 84: 172-180.

Schneider, F., Kallis, G. and J. Martinez-Alier. 2010. Crisis or opportunity? Economic degrowth for social equity and ecological sustainability. Introduction to this special issue. Journal of Cleaner Production 18(6): 511-518.

Kapp, K.W. 1950. The social costs of private enterprise. Cambridge: Harvard University Press.

Kempf, H. 2007. Comment les riches détruisent la planète. Paris: Seuil.

Khan, M.T. 2011. The Nishorgo Support Project, the Lawachara National Park, and the Chevron seismic survey: forest conservation or energy procurement in Bangladesh? Journal of Political Ecology 17: 68-78.

Kowasch, M. 2012. Le développement de l'industrie du nickel et la transformation de la valeur environnementale en Nouvelle- Calédonie. Journal of Political Ecology 19: 202-220.

Latouche, S. 2009. Farewell to growth. Cambridge: Polity.

Lefebvre H. 1968. Le droit à la ville. Paris: Anthropos.

Lefebvre H. 1972. Espace et politique; le droit à la ville II. Paris: Éditions Anthropos.

Lefebvre H., edited by Kofman E. and E. Lebas. 1996. Writings on cities. Oxford: Blackwell.

Lerner S. 2010, Sacrifice zones: the front lines of toxic chemical exposure in the United States. Cambridge: MIT Press.

Loh, P. and P. Eng. 2010. Environmental justice and the green economy: a vision statement and case studies for just and sustainable solutions. Boston: Alternatives for Community and the Environment.

Loh, P. and J. Sugerman-Brozan. 2002. Environmental justice organizing for environmental health: case study on asthma and diesel exhaust in Roxbury, Massachusetts. Annals of the American Academy of Political and Social Science 584: 110-124.

Lucas K. 2004. Running on empty: transport, social exclusion and environmental justice. Bristol: The Policy Press. 
Maantay, J. 2007. Asthma and air pollution in the Bronx: methodological and data considerations in using GIS for environmental justice and health research. Health and Place 13: 32.

MacGregor, S. 2004. From care to citizenship: calling ecofeminism back to politics. Ethics and the Environment 9 (1): 56-84.

Mallon, F.E. 1983. The defense of community in Peru's Central Highlands: peasant struggle and capitalist transition, 1860-1940. Princeton University Press.

Marcuse P. (ed.) 2009. Searching for the just city: debates in urban theory and practice. London: Routledge.

Martin Beristain M., C., Paez. D.M. and I. Fernandez. 2009. Las palabras de la selva: estudio psicosocial del impacto de las explotaciones petroleras de Texaco en las comunidades amazónicas de Ecuador. Bilbao: Heoga.

Martinez-Alier, J. 1992. De la economía ecológica al ecologismo popular. Barcelona: Icaria.

Martinez-Alier, J. 1993. Distributional obstacles to international environmental policy: the failures at Rio and prospects after Rio. Environmental Values 2(2): 97-124.

Martinez-Alier, J. 1997. Environmental justice (local and global). Capitalism, Nature, Socialism 8(1): 91107.

Martinez-Alier, J. 2002. The environmentalism of the poor: a study of ecological conflicts and valuation. Cheltenham: Edward Elgar.

Martinez-Alier, J. 2009. Social metabolism, ecological distribution conflicts, and languages of valuation. Capitalism, Nature, Socialism 20(1): 58-87.

Martinez-Alier, J. 2011. The EROI of agriculture and its use by the Via Campesina. Journal of Peasant Studies 38(1): 145-160.

Martinez-Alier, J. 2012a. Biopiratería: una palabra que triunfa. La Jornada (Mexico) 14 December 2012. http://www.jornada.unam.mx/2012/12/14/opinion/018a1pol

Martínez-Alier, J. 2012b. Environmental justice and economic degrowth: an alliance between two movements. Capitalism, Nature, Socialism 23(1): 51-73.

Martinez-Alier, J. 2014. The environmentalism of the poor. Geoforum in press

Martinez-Alier, J., Healy, H., Temper, L., Walter, M., Rodriguez-Labajos, B., Gerber, J-F., and M. Conde. 2011. Between science and activism: learning and teaching ecological economics with environmental justice organisations. Local Environment 16 (1): 17-36.

Martinez-Alier J., G. Kallis, S. Veuthey, M. Walter and L. Temper. 2010. Social metabolism, ecological distribution conflicts, and valuation languages. Ecological Economics 70(2):153-158.

Martinez-Alier, J., Pascual, U., Vivien, F. and E. Zaccai. 2010. Sustainable de-growth: mapping the context, criticisms and future prospects of an emergent paradigm. Ecological Economics 69 (9): 1741-1747.

Massari, M. 2003. The illegal trafficking in hazardous waste in Italy and Spain: final report. Rome, Italy: Gruppo Abele-Nomos, Legambiente, GEPEC-EC. 96 p. http://www.organized-crime.de/revgru03.htm

Max-Neef, M. and S. Kumar. 1991. How much is enough? London: Phil Shepherd Production.

McAfee, K. 2008. Beyond techno-science: transgenic maize in the fight over Mexico's future. Geoforum 39(1): 148-160.

McKibben, B. 1989. The end of nature. Random House. (serialized in the New Yorker, 1988)

McCully, P. 1996. Silenced rivers: the ecology and politics of large dams. London: Zed Books. sections

Meadows, D.H., Meadows, D.L. and J. Randers. 2004. Limits to growth: the 30-year update. Chelsea Green.

Meadows, D.H., Meadows, D.L. and J. Randers. 1972. Limits to growth. Universe Books.

Mellor, M. 1997. Feminism and ecology. New York: University Press.

Mellor, M. 2006. Ecofeminist political economy. International Journal of Green Economy 1: 139-150.

Mitchell, D. 2003. The right to the city: social justice and the fight for public space. New York: The Guilford Press.

Mitchell, G. and D. Dorling. 2003. An environmental justice analysis of British air quality. Environment and Planning A 35: 909-929. 
Mooney, P. 2000. Why we call it Biopiracy? In Svarstad, H. and Dhillion, S.S. (eds.) Responding to bioprospecting: from biodiversity in the south to medicines in the North. Oslo: Spatacus. Pp. 37-44.

Moore, J. 2000. Sugar and the expansion of the early modern world economy: commodity frontiers, ecological transformation, and industrialization. Part 1. Review (Fernand Braudel Center) 23 (3): 409433.

Motavalli, J. 2011. How dirty towels impacted the green movement. The Daily Finance. http://www.dailyfinance.com/2011/02/12/the-history-of-greenwashing-how-dirty-towels-impactedthe-green (accessed March 28th, 2013)

Müller, B., Höhne N. and C. Ellermann. 2009. Differentiating (historic) responsibilities for climate change. Climate Policy 9: 593-611.

Neumayer, E. 2000. In defence of historical accountability for greenhouse gas emissions. Ecological Economics 33: 185-192.

Nixon, R. 2011. Slow violence and the environmentalism of the poor. Cambridge: Harvard University Press.

Odum, H.T. and E.C. Odum. 2001. The prosperous way down. Boulder: University Press of Colorado.

O'Hara, S. 2009. Feminist ecological economics: theory and practice. In Salleh, A. (ed.). Eco-sufficiency and global justice. New York: Pluto Press. Pp 152-175.

Ojo, G.U. 2013. Against the expansion of the oil frontier: historicizing civil society initiatives to Leave Oil in the Soil in Nigeria. In L. Temper et al. 2013. Towards a post-oil civilization: Yasunization and other initiatives to leave fossil fuels in the soil. EJOLT Report No. 6. Pp. 35-46.

Ostrom, E. 1990. Governing the commons: the evolution of institutions for collective action. Cambridge: Cambridge University Press.

Overbeek,W, Kröger M. and J.-F. Gerber. 2012. An overview of industrial tree plantation conflicts in the global South. Conflicts, trends, and resistance struggles. EJOLT Report No. 3. 100 p.

Paredis, E., G. Goeminne, W. Vanhove, F. Maes and J. Lambrecht. 2008. The concept of Ecological Debt: its meaning and applicability in international policy. Ghent: Academia Press.

Paredis, E., J. Lambrecht, G. Goeminne and W. Vanhove. 2004. VLIR-BVO Project 2003. Elaboration of the concept of ecological debt. Final report. Ghent: Centre for Sustainable Development (CDO), Ghent University. $\quad$ http://www.ecologicaldebt.org/What-is-Ecological-Debt/Elaboration-of-the-conceptofecological-debt.html

Pellow D.N. 2000. Environmental inequality formation: toward a theory of environmental justice. American Behavioral Scientist 43: 581-601.

Pellow D.N. 2002 Garbage wars : the struggle for environmental justice in Chicago. Cambridge: The MIT Press.

Pellow D.N and L.S-H. Park. 2002. The Silicon Valley of dreams: environmental injustice, immigrant workers, and the high-tech global economy. New York: New York University Press.

People's World Conference on Climate Change and the Rights of Mother Earth [PWCCC] (2010): People's Agreement. http://www.pwccc.wordpress.com/2010/04/24/peoplesagreement

People's Summit 2012. Final declaration. http://rio20.net/en/propuestas/finaldeclaration-of-thepeople\%E2\%80\%99s-summit-in-rio-20

Peralta, A.K. (ed.) 2006. Ecological debt: the peoples of the South are the creditors. Cases from Ecuador, Mozambique, Brazil and India. Geneva: World Council of Churches. intro

Perkins, E. and E. Kuiper. 2005. Exploration: feminist ecological economics. Feminist Economics 11: 107150.

Perkins, E. 2007. Feminist ecological economics and sustainability. Journal of Bioeconomy 9: 227-244.

Pigrau A., Borràs, S., Jaria i Manzano, J. and A. Cardesa-Salzmann. 2012. Legal avenues for EJOs to claim environmental liability. EJOLT Report No. 4.98 p.

Pigrau, A., Borras, S. Cardesa-Salzmann, A. and J. Jaria i Manzano. 2013. International law and ecological debt. International claims, debates and struggles for environmental justice. EJOLT Report no. 11. 128p. 
Polanyi, K. 1944. The great transformation. New York: Rinehart.

Porto, M.F. 2012a. Complexity, vulnerability processes and environmental justice: an essay in political epistemology. RCCS Annual Review 4: 41-68.

Porto, M.F. 2012b. Movements and the network of environmental justice in Brazil. Environmental Justice 5(2): 100-104.

Porto, M.F. and R. Finamore. 2012. Environmental risk, health and justice: the protagonism of affected populations in the production of knowledge. Ciência saúde coletiva 17 (6): 1493-1501.

Porto, M.F., Pacheco, T. and J.P. Leroy (eds.). 2013. Injustiça ambiental e saúde no Brasil: o mapa de conflitos. Rio de Janeiro: Fiocruz.

Ramose, M.B, 2002. The ethics of Ubuntu. In A.P.J. Roux and P.H. Coetzee (eds.) The African philosophy reader. Cape Town: Oxford University Press.

Raventós, D. 2007. Basic income. London: Pluto Press.

Renting, H., Schermer, M. and A. Rossi. 2012. Building food democracy: exploring civic food networks and newly emerging forms of food citizenship. International. Journal of Sociology of Agriculture and Food 19 (3): 289-307.

Research \& Degrowth. 2010. Degrowth Declaration of the Paris 2008 conference. Journal of Cleaner Production 6(18): 523-524.

Reuters 2009. U.S. will pay into climate fund, but not reparations: Todd Stern. http://www.reuters.com/article/2009/12/09/us-climate-copenhagen-sternidUSTRE5B82R220091209

Rice, J. 2009. North South relations and the ecological debt: asserting a counter-hegemonic discourse. Critical Sociology 35: 225-252.

Roberts, J.T. and B.C. Parks. 2007. A Climate of injustice: global inequality, North- South politics, and climate policy. Cambridge: The MIT Press.

Roberts, J.T. and B.C. Parks. 2009. Ecologically unequal exchange, ecological debt, and climate justice. The history and implications of three related ideas for a new social movement. International Journal of Comparative Sociology 50: 385-409.

Robinson, D.F. 2010. Confronting biopiracy. challenges, cases and international debates. London: Earthscan.

Robleto, M.L. and W. Marcelo. 1992. Deuda ecológica. Santiago de Chile: Instituto de Ecologia Politica.

Rocheleau, D., Thomas-Slayter, B. and E. Wangari (eds.). 1996. Feminist political ecology: global issues and local experiences. New York: Routledge.

Santos, B. de S. and C. Rodríguez-Garavito (eds.). 2005. Law and globalization from below: towards a cosmopolitan legality. Cambridge: Cambridge University Press.

Schindler, S., Demaria, F. and S.B. Pandit. 2012. Delhi's waste conflict. Economic and Political Weekly XLVII(42).

Schlosberg, D., 2007. Defining environmental justice: theories, movements and nature. Oxford: Oxford University Press.

Schlosberg, D. 1999. Environmental justice and the new pluralism: the challenge of difference for environmentalism. Oxford: Oxford University Press.

Schneider, F., Kallis G. and J. Martinez-Alier. 2010. Crisis or opportunity? Economic degrowth for social equity and ecological sustainability. Journal of Cleaner Production 18(6): 511-518.

Schneider, F., J. Martinez-Alier and G. Kallis. 2011. Sustainable Degrowth. Journal of Industrial Ecology 15: 654-656.

Schutter, O. de, 2012. From food security to food sovereignty. http://www.eesc.europa.eu/resources/docs/deschutter.pdf (accessed March 28th, 2013)

Sekulova, F., Kallis G., Rodríguez-Labajos B. and F. Schneider. 2013. Degrowth: from theory to practice. Journal of Cleaner Production 28: 1-6. 
Sharife, K. and P. Bond. 2012. South Africa's minerals energy complex. In Healy, H., J. Martinez-Alier, L. Temper, M. Walter, and J.F. Gerber (eds.). Ecological economics from the ground up. London: Routledge.

Shaw, H.J. 2014. The consuming geographies of food diet, food deserts and obesity. New York: Routledge.

Shiva, V. 1997. Biopiracy: the plunder of nature and knowledge. Boston: South End Press.

Shrivastava, A. and A. Kothari. 2012. Churning the Earth: the making of modern India. New Delhi: Penguin Viking.

Shue, H. 1994. Subsistence emissions, luxury emissions. Law and Policy 15: 39-59.

Shue, H. 1999. Global environment and international inequality. International Affairs 75: 531-545.

Sikor, T. and P. Newell (eds.). 2014. Globalising environmental justice? Special journal issue forthcoming in Geoforum.

Simms, A. 2005. Ecological debt: the health of the planet and the wealth of nations. London: Pluto Press.

Simms, A. 2009: Ecological debt: global warming and the wealth of nations. $2^{\text {nd }}$ ed. London: Pluto Press.

Simms, A., A. Meyer and N. Robins. 1999. Who owes who? Climate change, debt, equity and survival. London: Christian Aid. http://www.ecologicaldebt.org/Whoowes-Who/Who-owes-who-Climatechange-dept-equity-and-survival.html

Smith T, Sonnenfeld D.A. and D.N. Pellow. 2006. Challenging the chip: labor rights and environmental justice in the global electronics industry. Philadelphia: Temple University Press.

Smith, K.R. 1996. The natural debt: North and South. In Giambellucu, T.W. and A. Henderson-Sellers (eds.) Climate change: developing southern hemisphere perspectives. Chicester/New York: John Wiley.

Soja, E.W. 2010. Seeking spatial justice. Minneapolis: University of Minnesota Press.

Spangenberg, J. (ed.) 1995. Towards sustainable Europe: a study from the Wuppertal Institute for Friends of the Earth Europe. Luton/Brussels: FoE Publications Ltd.

Srinivasan, U.T., S.P. Carey, E. Hallstein, P.A.T. Higgins, A.C. Kerr, L.E. Koteen, A.B. Smith, R. Watson, J. Harte and R.B. Norgaard. 2008. The debt of nations and the distribution of ecological impacts from human activities. Proceedings of the National Academy of Sciences 105(5): 1768-1773.

Svampa, M. 2013. "Consenso de los commodities" y lenguajes de valoración en América Latina. Nueva Sociedad 244: 30-46.

Sze J. 2006. Noxious New York: the racial politics of urban health and environmental justice. Boston: The MIT Press.

Temper, L., Yánez, I., Sharife, K., Ojo, G., Martinez-Alier, J., CANA, Combes, M., Cornelissen, K., Lerkelund, H., Louw, M., Martínez, E., Minnaar, J., Molina, P., Murcia, D., Oriola, T., Osuoka, A., Pérez, M. M., Roa Avendaño, T.,Urkidi, L., Valdés, M., Wadzah, N. and S. Wykes. 2013. Towards a post-oil civilization: Yasunization and other initiatives to leave fossil fuels in the soil. EJOLT Report No. 6, 204 p.

The Guardian. 2008. Rich countries owe poor a huge environmental debt. http://www.guardian.co.uk/science/2008/jan/21/environmental.debt1?INTCMP=SRCH

Thompson, E.P. 1971. The moral economy of the english crowd in the 18th Century. Past \& Present, 50: 76136.

Trainer, T. 1985. Abandon affluence! London: Zed.

TWN. 2009a. Repay the climate debt: a just and effective outcome for Copenhagen. Penang: Third World Network.

TWN. 2009b. Repay the climate debt: list of endorsements. Penang: Third World Network. http://www.twnside.org.sg/announcement/sign-on.letter_climate.dept.htm

TWN. 2010. Sign-on letter calling for repayment of climate change. Penang: Third World Network. http://www.twnside.org.sg/announcement/sign-on.letter_climate.dept.htm

Torras, M. 2003. An ecological footprint approach to external debt relief. World Development 31: 21612171. 
UNFCCC. 2009. Commitments for Annex 1 Parties under paragraph 1(b)(i) of the Bali Action Plan: Evaluating developed countries' historical climate debt to developing countries. Submission by the Republic of Bolivia to AWG-LCA. http://unfccc.int/resource/docs/2009/awglca6/eng/misc04p01.pdf

UNFCCC. 2010c. FCCC/AWGLCA/2010/MISC.2. Additional views on which the chair may draw in preparing text to facilitate negotiations among parties. Submissions from Parties. Bonn: UNFCCC. http://unfccc.int/resource/docs/2010/awglca10/eng/misc02.pdf

United Nations [UN] 2009. World economic and social survey 2009: promoting development, saving the planet. New York: UN, Department of Economic and Social Affairs. http://www.un.org/esa/policy/wess/

United Nations Convention on Climate Change [UNFCCC] 1997. Paper No. 1: Brazil: proposed elements of a protocol to the United Nations Framework Convention on Climate Change. Presented by Brazil in response to the Berlin Mandate. UNFCCC/AGBM/1997/MISC.1/Add.3 GE.97-. http://unfccc.int/cop3/resource/docs/1997/agbm/misc01a3.htm

United Nations Development Program [UNDP] (2007): Human Development Report 2007/2008: Fighting Climate Change. Human Solidarity in a divided world. New York: UNDP. http://hdr.undp.org/en/reports/global/hdr2007-2008/

Utting, P. 2008. Social and environmental liabilities of transnational corporations: new directions, opportunities and constraints. In Clapp, J. and P. Utting (eds.) Corporate accountability and sustainable development. Delhi: Oxford University Press.

Vanderheiden, S. 2008. Atmospheric justice: a political theory of climate change. Oxford: Oxford University Press.

Varga, C., Kiss I. and I. Ember. 2002. The lack of environmental justice in Central and Eastern Europe. Environmental Health Perspectives 110: 662-663.

Veuthey, S. and J.-F. Gerber. 2010. Logging conflicts in Southern Cameroon: a feminist ecological economics perspective. Ecological Economics 70(2): 170-177.

Veuthey, S. and J.-F. Gerber. 2012. Accumulation by dispossession in coastal Ecuador: shrimp farming, local resistance and the gender structure of mobilizations. Global Environmental Change 22(3): 611-622.

Victor, P. 2008. Managing without growth: slower by design, not disaster. Cheltenham: Edward Elgar.

Waring, M. 1988. If women counted: a new feminist economics. San Francisco: Harper and Row.

Warlenius, R., Pierce, G., Malm, A., Oulu, M., Ramasar, V. and A. Hornborg. 2013. Reversing the arrow of arrears: a primer on the concept of "ecological debt" and its value for environmental justice. An EJOLT paper. Lund University: Human Ecology Division. 7 March 2013.

Warlenius, R. 2012. Calculating climate debt: a proposal. Paper submitted to ISEE 2012. Department of Human Ecology, Lund University. www.isee2012.org/anais/pdf/918.pdf

Warlenius, R. 2013. In defence of climate debt: a reply to Olivier Godard. Working Papers in Human Ecology No. 5. Lund University.

Weterings R. and J.B. Opschoor. 1994. Towards environmental performance indicators based on the notion of environmental space : report to the Advisory Council for Research on Nature and Environment, the Netherlands. Rijswijk, Netherlands: Advisory Council for Research on Nature and Environment (RMNO).

WCD. 2000. Dams and development: a new framework for decision-making. World Commission on Dams.

World Rainforest Movement (WRM) 2010. RSPO: The "greening" of the dark palm oil business. World Rainforest Movement.

Xue, J., Arler, F. and P. Næss. 2012. Is the degrowth debate relevant to China? Environment, Development and Sustainability 14 (1): 85-109.

Zierler, D. 2011. The invention of ecocide: Agent Orange, Vietnam, and the scientists who changed the way we think about the environment. Athens: University of Georgia Press. 